\title{
Interactions of Two Large Antiviral Polyamides with the Long Control Region of HPV16
}

Elena Vasilieva, Jacquelyn Niederschulte, Yang Song, George Davis Harris, Jr., Kevin J. Koeller, Puhong Liao, James K. Bashkin, Cynthia M. Dupureur*

Department of Chemistry \& Biochemistry and the Center for Nanoscience, University of Missouri St. Louis, St. Louis, MO 63121

*Corresponding author. Tel: 314-516-4392; FAX: 314-516-5342; cdup@umsl.edu. 


\section{ABSTRACT}

PA1 and PA25 are large hairpin polyamides that are effective in nearly eliminating HPV16 episomes (DNA) in cell culture, and PA25 has broad spectrum activity against three cancer-causing forms of HPV (Edwards, T. G., Koeller, K. J., Slomczynska, U., Fok, K., Helmus, M., Bashkin, J. K., Fisher, C., Antiviral Res. 91 (2011) 177-186).

Described here are the interactions of these PAs with sequences in the long control region (LCR) of HPV16 (7348-122). Using an FeEDTA conjugate of PA1 (designed to recognize $5^{\prime}-W_{2} G_{7}-3^{\prime} ; W=A$ or $T$ ), 34 affinity cleavage $(A C)$ patterns were detected for this fragment. These sites can be rationalized with sequences featuring perfect, single, double, triple and quadruple mismatches. Quantitative DNase I footprinting analysis indicates that perfect sites bind PA1 with $\mathrm{K}_{d} \mathrm{~S}$ between $0.7-2.2 \mathrm{nM} . \mathrm{K}_{d} \mathrm{~S}$ for single, double, triple and quadruple mismatch sites range from 1-3 nM to $20 \mathrm{nM}$. Using AC and EDTA conjugates, we report that unlike smaller 8-ring hairpin PAs, introduction of a chiral turn in this large polyamide has no effect on binding orientation (forward vs. reverse). Despite its design to recognize 5'- $\mathrm{W}_{2} \mathrm{GW}_{5} \mathrm{GW}_{4}-3^{\prime}$ via two Im residues, a motif not represented in this HPV sequence, a PA25-EDTA conjugate yielded 31 affinity cleavage sites on the region. Low $n M K_{d} S$ for PA25 without EDTA indicate a high tolerance for triple and quadruple mismatches. While there is extensive coverage of the sequence examined, AC cleavage patterns for the two PAs show discrete binding events and do not overlap significantly. This indicates that within the context of $A / T$ rich sequences, these PAs do not recognize a simple shared sequence-related feature of the DNA. These insights continue to inform the complex nature of large hairpin PA-DNA interactions and antiviral behavior. 
KEYWORDS: affinity cleavage, antiviral, binding constant, capillary electrophoresis, DNase I footprinting, polyamide

ABBREVIATIONS: AC, affinity cleavage; CE, capillary electrophoresis; DIEA, N,N-

Diisopropylethylamine; DMF, dimethylformamide; DTT, dithiothreitol; EDTA, ethylene diamine tetraacetic acid; LCR, long control region; TFA, trifluoroacetic acid. 


\section{INTRODUCTION}

Hairpin polyamides (PAs) are small polymers composed principally of pyrrole and imidazole. They are inspired by the crescent-shaped distamycin, a natural product that recognizes the hydrogen bonding patterns in AT rich sequences in the minor groove of DNA. Due to the elegant design but high toxicity, these natural products have evolved synthetically over a number of years to achieve high DNA affinity and reported sequence specificity [1-10] and have been subsequently applied to control the expression of genes $[3,11]$ and as chemical probes of nucleic acid structure [12].

A number of larger hairpin PAs (10 or more rings) have been shown to practically eliminate the HPV genome in cell culture with low $\mathrm{IC}_{50}$ S and no detectable toxicity $[13$, 14]. The two lead compounds reported in this anti-HPV study are PA1 and PA25 (Fig. 1), compounds that exhibit $I_{50}$ 's of 0.1 and $0.036 \mu \mathrm{M}$ against HPV16, respectively. Recently, the mechanism of action of this class of anti-HPV compounds has been partly elucidated in several reports that show an important role of the DNA Damage Response (DDR) modulated by PA administration to cells bearing small, circular dsDNA viral genomes, or episomes [14-16]. The access of these PAs to a DDR-related mechanism was unprecedented for any polyamides. Since our initial work was published, Dervan has reported other significant noncanonical PA influences on the DDR [17], though the mechanism seems largely unrelated since it does not depend on the presence of small, supercoiled circular dsDNA molecules. 
In our recent studies of the interactions of PA1 with a $524 \mathrm{bp}$ fragment of the E1 gene region of HPV16, we noted that even though only three perfect sites were predicted, 19 binding events were characterized using a combination of DNAse I footprinting and affinity cleavage. All of these could be rationalized as perfect, single or double mismatch sites, with the two former types of sites having indistinguishable $K_{d}$ values. Such tolerance for mismatch sequences is not universal among the more extensively characterized 8-ring hairpin PAs, as far as we know. For example, among 8ring PAs, single mismatch sites are bound with $K_{d}$ values $1-7$ to 26 - 55 times weaker than cognate (perfect) sites [18]. The density and degree of overlap of sites can be attributed in part to the AT-rich nature of the HPV genome.

Our initial results led to additional questions. For example, given that the antiviral PAs are larger and distinct from their 8-ring hairpin cousins, how well do they tolerate sites with a greater number of mismatches? Another issue that emerged is the binding orientation. In theory, hairpin PAs can bind in either forward (the $\mathrm{N}$ terminal Im of the PA aligns with the 5' end of the duplex) or reverse orientation (the $\mathrm{C}$ terminal Im of the PA aligns with the 5' end of the duplex) (Fig. 1). Among the 8-ring PAs, the forward orientation is generally considered preferable ([19]; vide infra); the combination of high AT density of the HPV genome and the apparently greater tolerance for mismatches indicate that larger PAs like PA1 might behave differently with respect to binding orientation. These issues could have significant implications for the mechanism of action of larger PAs (binding ten more bp) that show significant anti-HPV activity and in some cases show broad-spectrum anti-HPV activity $[13,20]$. 
It is therefore imperative that we understand that mechanism on a molecular scale, approaching it from chemical, biophysical and biological perspectives. Here we address these issues with a comparative biophysical study of two antiviral PAs, PA1 and PA25, and their interactions with the long control region (LCR) region of HPV16.

\section{MATERIALS AND METHODS}

\subsection{Polyamide Preparation.}

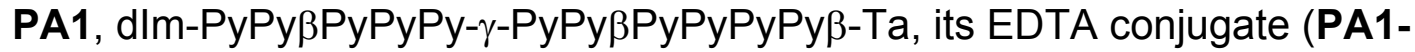
EDTA) and PA25 were prepared as previously described (PA1, PA25) [13, 21]. Minimal details (HRMS only) were given to characterize PA1 and PA25 in a biology report [13], so their $600 \mathrm{MHz}{ }^{1} \mathrm{H}$ and corresponding ${ }^{13} \mathrm{C}$ NMR data are reported here.

The building blocks used were amino acids and amines with the following abbreviations: Im = imidazole or N-methyl-2-carboxy-4-amino-imidazole, d $\mathrm{lm}=$ desamino-imidazole or N-methyl-2-carboxy-imidazole, $\mathrm{Py}=$ pyrrole or N-methyl-2carboxy-4-amino-pyrrole, $\beta=\beta$-alanine, $\gamma=\gamma$ aminobutyric acid $\gamma\left(\mathrm{NH}_{2}\right)=(\mathrm{R})-2-\mathrm{Cbz}-4-$ Boc-diaminobutyric acid yielding (R)-2,4-diaminobutyric acid incorporated into the PA via the acid and 4-amino group after all deprotection; Ta is the amino tail at PA Cterminus formed from $\mathrm{NMe}\left(\mathrm{CH}_{2} \mathrm{CH}_{2} \mathrm{CH}_{2} \mathrm{NH}_{2}\right)_{2}$. New compounds PA2, PA2-EDTA (or amino-PA1) and PA25-EDTA were prepared by analogy with PA1 and PA1-EDTA, based on literature [21, 22]. For new polyamide PA2, purity was assessed by two orthogonal analytical HPLC methods, one using a Phenomenex Jupiter ${ }^{\circledR}$ Proteo C12 RP column (90 A, 4 um) with mobile phase of $\left(\mathrm{A}: 0.1 \% \mathrm{HCO}_{2} \mathrm{H}\right.$ in $\mathrm{H}_{2} \mathrm{O}$; $\left.\mathrm{B}: \mathrm{MeCN}\right)$ and the a 
Phenomenex Synergi Polar-RP column (80 A, 4 um) with mobile phase (A: $0.1 \%$ $\mathrm{NH}_{4} \mathrm{OH}$ in $\mathrm{H}_{2} \mathrm{O}$; $\mathrm{B}$ : MeCN). Analytical HPLC with in-line diode array and MS employed an Agilent 1100 or 1200 HPLC with thermostatted column compartment and Agilent 1956B MSD single quadrupole mass spec detector, $\mathrm{m} / \mathrm{z}$ range up to 3,000 . HRMS was carried out at the proteomics center of the Donald J. Danforth Plant Sciences Center or by Prof. B. J. Bythell of UMSL.

PA stocks were prepared by dissolving in $100 \%$ DMSO and quantitated using an extinction coefficient of $92,600 \mathrm{M}^{-1} \mathrm{~cm}^{-1}$ at $305 \mathrm{~nm}$ (PA1, PA2 and derivatives), or 91,700 $\mathrm{M}^{-1} \mathrm{~cm}^{-1}$ at $305 \mathrm{~nm}$ (PA25 and derivatives). Both values were obtained via fluorescence assay [23].

PA2 precursor dlm-PyPy- $\beta-P y P y P y-\gamma_{(\mathrm{NHCbz})}-\mathrm{PyPy}-\beta-\mathrm{PyPyPyPy}-\beta-$ Ta and PA2 (i.e. amino-PA1) dlm-PyPy- $\beta-P y P y P y-\gamma_{(\mathrm{NH} 2)}-\mathrm{PyPy}-\beta-\mathrm{PyPyPyPy}-\beta-\mathrm{Ta}$ were prepared and characterized by methods analogous to the literature $[13,22,24]$.

\section{PA1 ImPyPy- $\beta-P y P y P y-\gamma-P y P y-\beta-P y P y P y P y-\beta-T a(3$ TFA):}

${ }^{1} \mathrm{H}$ NMR $\left(600 \mathrm{MHz}, \mathrm{DMSO}-\mathrm{d}^{6}\right) \mathrm{d}=10.46$ (s, $\left.1 \mathrm{H}\right), 9.93$ (s, $\left.1 \mathrm{H}\right), 9.91$ (s, $\left.4 \mathrm{H}\right)$, 9.90 - 9.87 (m, 2 H), 9.86 (s, 1 H), 9.83 (s, 1 H), 9.63 (br. s., 2 H), 8.12 - 8.02 (m, 5 H), 7.98 - 7.92 (m, 1 H), 7.88 (br. s., 3 H), 7.40 (s, 1 H), 7.28 (d, J = 1.8 Hz, 1 H), 7.24 $7.21(m, 3 \mathrm{H}), 7.21$ - $7.18(\mathrm{~m}, 4 \mathrm{H}), 7.18$ - $7.16(\mathrm{~m}, 3 \mathrm{H}), 7.15(\mathrm{~d}, \mathrm{~J}=1.8 \mathrm{~Hz}, 1 \mathrm{H}), 7.08$ $(\mathrm{d}, J=1.8 \mathrm{~Hz}, 1 \mathrm{H}), 7.07(\mathrm{~d}, J=1.8 \mathrm{~Hz}, 1 \mathrm{H}), 7.06(\mathrm{~s}, 1 \mathrm{H}), 7.04(\mathrm{~d}, J=1.8 \mathrm{~Hz}, 1 \mathrm{H})$, $6.90(\mathrm{~d}, J=1.8 \mathrm{~Hz}, 1 \mathrm{H}), 6.89(\mathrm{~d}, \mathrm{~J}=1.8 \mathrm{~Hz}, 1 \mathrm{H}), 6.89(\mathrm{~s}, 2 \mathrm{H}), 6.85(\mathrm{~s}, 2 \mathrm{H}), 6.84(\mathrm{~d}, J$ $=1.2 \mathrm{~Hz}, 1 \mathrm{H}), 3.99(\mathrm{~s}, 3 \mathrm{H}), 3.85(\mathrm{~s}, 3 \mathrm{H}), 3.85(\mathrm{~s}, 3 \mathrm{H}), 3.84(\mathrm{~s}, 9 \mathrm{H}), 3.82(\mathrm{~s}, 6 \mathrm{H}), 3.81$ 
(s, $3 \mathrm{H}), 3.81(\mathrm{~s}, 9 \mathrm{H}), 3.49-3.42(\mathrm{~m}, 4 \mathrm{H}), 3.41-3.35(\mathrm{~m}, 4 \mathrm{H}), 3.25-3.16(\mathrm{~m}, 4 \mathrm{H})$,

3.16 - 3.10 (m, 2 H), 3.10 - $2.98(m, 4$ H), 2.87 (br. s, 2 H), $2.74(d, J=4.7$ Hz, $3 \mathrm{H})$,

$2.55-2.51(\mathrm{~m}, 2 \mathrm{H}), 2.36(\mathrm{t}, J=7.0 \mathrm{~Hz}, 2 \mathrm{H}), 2.28(\mathrm{t}, J=7.3 \mathrm{~Hz}, 2 \mathrm{H}), 1.96-1.87(\mathrm{~m}, 2$

$\mathrm{H}), 1.82-1.74(\mathrm{~m}, 2 \mathrm{H})$

${ }^{13} \mathrm{C}$ NMR $\left(151 \mathrm{MHz}\right.$, DMSO-d $\left.{ }^{6}\right) d=171.1,169.3,167.9,167.8,161.3,158.6,158.5$, 158.5, 158.4, 158.4, 158.4, 158.1, 157.9, 155.9, 138.7, 126.8, 126.3, 123.0, 122.9, $122.8,122.8,122.8,122.7,122.7,122.2,122.2,122.1,122.1,122.1,122.0,121.9$, 121.4, 118.6, 118.5, 118.4, 118.2, 118.1, 118.0, 117.8, 104.9, 104.8, 104.8, 104.7, $104.3,104.3,104.2,104.0,104.0,103.9,53.3,52.1,40.0,39.3,38.2,36.2,36.1,36.1$, $36.0,35.8,35.8,35.6,35.6,35.5,35.4,35.1,33.3,25.7,24.0,21.8$

\section{PA2 (Amino-PA1) dlmPyPy- $\beta-P y P y P y-\gamma(\mathrm{NH2})-\mathrm{PyPy}-\beta-\mathrm{PyPyPy}$ - $y-\beta-T a(4 \mathrm{TFA}):$}

${ }^{1} \mathrm{H}$ NMR $\left(600 \mathrm{MHz}, \mathrm{DMSO}-\mathrm{d}^{6}\right) \delta=10.56(\mathrm{~s}, 1 \mathrm{H}), 10.45(\mathrm{~s}, 1 \mathrm{H}), 9.93(\mathrm{~s}, 2 \mathrm{H})$, $9.91(\mathrm{~s}, 5 \mathrm{H}), 9.89(\mathrm{~s}, 1 \mathrm{H}), 9.61-9.53(\mathrm{~m}, 1 \mathrm{H}), 8.35-8.25(\mathrm{~m}, 3 \mathrm{H}), 8.23(\mathrm{t}, \mathrm{J}=5.3 \mathrm{~Hz}$, 1 H), 8.12 - 8.01 (m, 4 H), 7.91 (br. s, 2 H), 7.85 (br. s., 3 H), 7.39 (s, 1 H), 7.28 (d, J = $1.8 \mathrm{~Hz}, 1 \mathrm{H}), 7.24(\mathrm{~d}, J=1.2 \mathrm{~Hz}, 1 \mathrm{H}), 7.22(\mathrm{~s}, 2 \mathrm{H}), 7.21(\mathrm{~d}, J=1.8 \mathrm{~Hz}, 1 \mathrm{H}), 7.20-$ $7.17(\mathrm{~m}, 4 \mathrm{H}), 7.16(\mathrm{~d}, \mathrm{~J}=1.8 \mathrm{~Hz}, 1 \mathrm{H}), 7.15(\mathrm{~d}, \mathrm{~J}=1.8 \mathrm{~Hz}, 1 \mathrm{H}), 7.11(\mathrm{~s}, 1 \mathrm{H}), 7.09(\mathrm{~d}$, $J=1.2 \mathrm{~Hz}, 1 \mathrm{H}), 7.07(\mathrm{~d}, J=1.2 \mathrm{~Hz}, 1 \mathrm{H}), 7.06(\mathrm{~d}, J=1.2 \mathrm{~Hz}, 1 \mathrm{H}), 7.05(\mathrm{~d}, J=1.2 \mathrm{~Hz}$, $1 \mathrm{H}), 7.03(\mathrm{~s}, 1 \mathrm{H}), 6.98(\mathrm{~d}, J=1.8 \mathrm{~Hz}, 1 \mathrm{H}), 6.93(\mathrm{~d}, J=1.8 \mathrm{~Hz}, 1 \mathrm{H}), 6.89(\mathrm{~d}, J=1.8$ $\mathrm{Hz}, 2 \mathrm{H}), 6.86(\mathrm{~d}, \mathrm{~J}=1.8 \mathrm{~Hz}, 1 \mathrm{H}), 6.85(\mathrm{~d}, \mathrm{~J}=1.8 \mathrm{~Hz}, 1 \mathrm{H}), 3.99(\mathrm{~s}, 3 \mathrm{H}), 3.85(\mathrm{~s}, 6 \mathrm{H})$, $3.84(\mathrm{~s}, 3 \mathrm{H}), 3.84(\mathrm{~s}, 3 \mathrm{H}), 3.84(\mathrm{~s}, 9 \mathrm{H}), 3.82(\mathrm{~s}, 9 \mathrm{H}), 3.80(\mathrm{~s}, 3 \mathrm{H}), 3.48$ - $3.42(\mathrm{~m}, 4 \mathrm{H})$, 3.42 - $3.35(m, 2 \mathrm{H}), 3.35$ - $3.23(\mathrm{~m}, 2 \mathrm{H}), 3.21$ - $3.16(\mathrm{~m}, 1 \mathrm{H}), 3.16$ - $3.09(\mathrm{~m}, 2 \mathrm{H}), 3.09$ 
- $2.98(m, 4 H), 2.91-2.82(m, 2 H), 2.74(d, J=4.7 \mathrm{~Hz}, 3 \mathrm{H}), 2.56-2.51(m, 4 \mathrm{H}), 2.36$

$(\mathrm{t}, J=7.3 \mathrm{~Hz}, 2 \mathrm{H}), 2.03-1.94(\mathrm{~m}, 2 \mathrm{H}), 1.94-1.86(\mathrm{~m}, 2 \mathrm{H}), 1.82-1.74(\mathrm{~m}, 2 \mathrm{H})$

${ }^{13} \mathrm{C}$ NMR $\left(151 \mathrm{MHz}\right.$, DMSO- $\left.\mathrm{d}^{6}\right) \delta=171.0,167.8,167.8,165.3,161.9,161.3,161.3$, 161.2, 158.5, 158.4, 158.3, 158.1, 158.1, 157.9, 157.6, 156.0, 138.7, 127.9, 126.8, 126.3, 123.2, 123.0, 122.8, 122.8, 122.7, 122.7, 122.7, 122.7, 122.4, 122.2, 122.2, 122.2, 122.2, 122.1, 122.1, 121.9, 121.4, 120.5, 118.6, 118.5, 118.4, 118.4, 118.4, $118.3,118.2,118.0,117.9,117.9,117.6,115.6,104.9,104.8,104.8,104.3,104.2$ 104.2, 104.0, 104.0, 53.3, 52.1, 50.8, 40.4, 40.0, 36.2, 36.2, 36.1, 36.1, 36.0, 36.0, 35.9, $35.8,35.6,35.5,35.5,35.4,35.1,24.0,21.8$

HRMS (ESI) calcd for $\mathrm{C}_{91} \mathrm{H}_{112} \mathrm{~N}_{32} \mathrm{O}_{16}[\mathrm{MH}]^{+}$, 1909.9012, found, 1909.9018. HPLC purity: $95 \%$.

The EDTA conjugate of PA2 was prepared via the same method as previously described for PA1-EDTA conjugate [21]. To a vigorously-stirred mixture of EDTA dianhydride (25 mg, $0.096 \mathrm{mmol}, 22 \mathrm{eq}$ ) in N,N-diisopropylethylamine (DIEA) (0.5 mL), DMF $(0.25 \mathrm{~mL})$ and DMSO $(0.25 \mathrm{~mL})$ at $55^{\circ} \mathrm{C}$ was added a mixture of Cbz-protected PA2 (12 mg, $0.0055 \mathrm{mmol}, 1 \mathrm{eq})$ in DIEA $(0.5 \mathrm{~mL})$ and DMF $(0.5 \mathrm{~mL})$ dropwise over a period of $30 \mathrm{~min}$. The reaction mixture was stirred at $55^{\circ} \mathrm{C}$ for $30 \mathrm{~min}$. Following addition of $0.1 \mathrm{~N} \mathrm{NaOH}(1.0 \mathrm{~mL})$, the mixture was stirred at $55^{\circ} \mathrm{C}$ for an additional 20 min. The bottom layer of the biphasic mixture was removed from the reaction vessel and neutralized with formic acid $(0.013 \mathrm{~mL})$. The mixture was diluted with $0.5 \mathrm{~mL} \mathrm{DMSO}$, filtered through a 20 um polyethylene filter, and purified by reversed-phase HPLC [A: $\mathrm{H}_{2} \mathrm{O}(0.1 \%$ TFA), B: $\mathrm{MeOH}]$ using a Phenomenex Jupiter $250 \times 30 \mathrm{~mm}, 5 \mathrm{um}, 100 \AA$, $\mathrm{C}_{18}(2)$ column. Concentration of pooled fractions checked by analytical HPLC/MS, 
followed by lyophilization gave the Cbz-protected PA2-EDTA conjugate $(9.9 \mathrm{mg}, 73 \%$ yield) as a white, fluffy solid.

The Cbz-protected PA2-EDTA conjugate $(3.7 \mathrm{mg}, 0.0015 \mathrm{mmol})$ was treated with $10 \%$ trifluoromethylsulfonic acid/trifluoroacetic acid $(0.30 \mathrm{~mL})$ at $25^{\circ} \mathrm{C}$ for 30 minutes to remove the Cbz-protecting group [25]. The mixture was then flash frozen with liquid nitrogen, treated with $\mathrm{N}, \mathrm{N}$-dimethylformamide $(0.30 \mathrm{~mL})$ and allowed to warm to $25^{\circ} \mathrm{C}$. The mixture was diluted with $\mathrm{N}, \mathrm{N}$-dimethylformamide $(0.30 \mathrm{~mL})$ and water $(0.30 \mathrm{~mL})$, filtered through a 20 um polyethylene filter, and purified by reversed-phase HPLC [A: $\mathrm{H}_{2} \mathrm{O}(0.2 \%$ formic acid), B: $\mathrm{MeOH}]$ using a Macherey Nagel $50 \times 21 \mathrm{~mm}, 5 \mathrm{um}$, $\mathrm{C}_{18}$ column. Concentration of pooled fractions, followed by lyophilization gave the desired EDTA conjugate, dlm-PyPy- $\beta-P y P y P y-\gamma(\mathrm{NH} 2)-P y P y-\beta-P y P y P y P y-\beta-T a-$ EDTA (2 $\left.\mathrm{HCO}_{2} \mathrm{H}\right)($ PA2-EDTA, i.e. amino-PA1-EDTA) $(3.0 \mathrm{mg}, 86 \%$ yield) as a white, fluffy solid: exact mass $[\mathrm{MH}]^{+}=2183.9813$, experimental $(\mathrm{ESI})[\mathrm{MH}]^{+}=2183.9727$.

\section{PA25 ImPyPy- $\beta-P y P y I m-\beta-P y P y-\gamma-P y P y-\beta-P y P y P y-\beta-P y P y P y-\beta-T a ~(4$ TFA):}

${ }^{1} \mathrm{H}$ NMR $\left(600 \mathrm{MHz}, \mathrm{DMSO}-\mathrm{d}_{6}\right) \mathrm{d}=10.46(\mathrm{~s}, 1 \mathrm{H}), 10.35(\mathrm{~s}, 1 \mathrm{H}), 9.95(\mathrm{~s}, 1 \mathrm{H})$,

$9.92(\mathrm{~s}, 1 \mathrm{H}), 9.91$ (s, $4 \mathrm{H}), 9.90$ - 9.87 (m, 2 H), 9.86 (s, $1 \mathrm{H}), 9.85$ (s, $1 \mathrm{H}), 9.82(\mathrm{~s}, 1 \mathrm{H})$,

9.59 (br. s., 2 H), 8.11 - 8.01 (m, 7 H), 7.97 - 7.91 (m, 2 H), 7.87 (br. s., 3 H), 7.51 (s, 1

H), $7.39(\mathrm{~s}, 1 \mathrm{H}), 7.32(\mathrm{~d}, J=1.8 \mathrm{~Hz}, 1 \mathrm{H}), 7.28(\mathrm{~d}, \mathrm{~J}=1.2 \mathrm{~Hz}, 1 \mathrm{H}), 7.23-7.21(\mathrm{~m}, 2 \mathrm{H})$,

$7.20(\mathrm{~d}, \mathrm{~J}=1.8 \mathrm{~Hz}, 1 \mathrm{H}), 7.20-7.18(\mathrm{~m}, 6 \mathrm{H}), 7.17-7.16(\mathrm{~m}, 2 \mathrm{H}), 7.16(\mathrm{~d}, \mathrm{~J}=1.8 \mathrm{~Hz}, 1$ H), $7.15(\mathrm{~d}, J=1.8 \mathrm{~Hz}, 1 \mathrm{H}), 7.07(\mathrm{~d}, J=1.2 \mathrm{~Hz}, 1 \mathrm{H}), 7.06-7.05(\mathrm{~m}, 2 \mathrm{H}), 7.04(\mathrm{~d}, J=$ $1.2 \mathrm{~Hz}, 1 \mathrm{H}), 6.89(\mathrm{~d}, \mathrm{~J}=1.2 \mathrm{~Hz}, 1 \mathrm{H}), 6.89-6.87(\mathrm{~m}, 4 \mathrm{H}), 6.87$ - $6.84(\mathrm{~m}, 4 \mathrm{H}), 6.84(\mathrm{~s}$, $1 \mathrm{H}), 3.99$ (s, $3 \mathrm{H}), 3.95$ (s, $3 \mathrm{H}), 3.84(\mathrm{~s}, 12 \mathrm{H}), 3.83(\mathrm{~s}, 6 \mathrm{H}), 3.82(\mathrm{~s}, 3 \mathrm{H}), 3.82(\mathrm{~s}, 6 \mathrm{H})$, 
$3.81(\mathrm{~s}, 6 \mathrm{H}), 3.80(\mathrm{~s}, 3 \mathrm{H}), 3.79(\mathrm{~s}, 6 \mathrm{H}), 3.57-3.50(\mathrm{~m}, 2 \mathrm{H}), 3.48$ - $3.42(\mathrm{~m}, 4 \mathrm{H}), 3.42$ - $3.34(\mathrm{~m}, 2 \mathrm{H}), 3.24$ - $3.16(\mathrm{~m}, 2 \mathrm{H}), 3.16$ - $3.09(\mathrm{~m}, 2 \mathrm{H}), 3.09$ - $2.98(\mathrm{~m}, 4 \mathrm{H}), 2.91$ $2.83(\mathrm{~m}, 4 \mathrm{H}), 2.74(\mathrm{~d}, \mathrm{~J}=4.7 \mathrm{~Hz}, 3 \mathrm{H}), 2.58-2.51(\mathrm{~m}, 6 \mathrm{H}), 2.36(\mathrm{t}, \mathrm{J}=7.0 \mathrm{~Hz}, 2 \mathrm{H})$, $2.27(\mathrm{t}, \mathrm{J}=7.6 \mathrm{~Hz}, 2 \mathrm{H}), 1.97-1.87(\mathrm{~m}, 4 \mathrm{H}), 1.78(\mathrm{td}, \mathrm{J}=6.6,13.8 \mathrm{~Hz}, 4 \mathrm{H})$ ${ }^{13} \mathrm{C}$ NMR $\left(151 \mathrm{MHz}\right.$, DMSO-d $\left.\mathrm{d}_{6}\right) \mathrm{d}=171.0,169.2,167.9,167.8,167.8,161.3,161.3$, 161.3, 158.8, 158.5, 158.5, 158.5, 158.4, 158.4, 158.3, 158.1, 157.9, 155.9, 138.7, $136.2,133.7,126.8,126.3,123.0,122.9,122.8,122.8,122.8,122.7,122.7,122.7$, $122.2,122.1,122.1,122.1,122.0,122.0,121.9,121.9,121.9,121.9,121.8,121.4$, 119.5, 118.6, 118.5, 118.2, 118.1, 117.9, 117.8, 117.5, 115.5, 114.4, 105.7, 104.9, $104.8,104.7,104.3,104.3,104.2,104.2,104.1,104.0,104.0,103.9,103.9,53.3,52.3$, $52.1,40.4,40.0,39.3,38.2,36.2,36.2,36.1,36.1,36.1,36.0,35.8,35.8,35.6,35.6$, $35.5,35.4,35.2,35.1,35.0,34.9,33.3,25.7,24.1,21.8,21.7$

HRMS (ESI) calcd for $\mathrm{C}_{120} \mathrm{H}_{144} \mathrm{~N}_{42} \mathrm{O}_{22}[\mathrm{MH}]^{+}, 2526.1447$, found, 2526.1557, HPLC purity: $98 \%$.

The EDTA conjugate of PA25 was prepared via the same method as previously described for PA1-EDTA conjugate [21]. $17 \mathrm{mg}(0.067 \mathrm{mmol})$ of EDTA dianhydride were stirred vigorously at $55^{\circ} \mathrm{C}$ in $0.5 \mathrm{~mL}$ DIEA, $0.25 \mathrm{~mL}$ DMF and $0.25 \mathrm{~mL}$ DMSO. To the anhydride, a biphasic mixture of $10 \mathrm{mg}(0.0034 \mathrm{mmol})$ PA25, $0.5 \mathrm{~mL}$ DIEA, and 0.5 mL DMF over 15 min via syringe. After HPLC (Phenomenex Jupiter $250 \times 21 \mathrm{~mm}, \mathrm{C}_{12}, 4$ u column, $\mathrm{A}: \mathrm{H}_{2} \mathrm{O} 0.1 \%$ TFA, B: $\left.\mathrm{MeOH}\right)$ and lyophilization, $3.5 \mathrm{mg}(0.0012 \mathrm{mmol}, 35 \%$ yield) of white fluffy solid were collected, PA25-EDTA ImPyPy- $\beta$-PyPyIm- $\beta$-PyPy- $\gamma$ PyPy- $\beta-P y P y P y-\beta-P y P y P y-\beta-T a-E D T A\left(2\right.$ TFA), LCMS $[\mathrm{M}+\mathrm{Na}+\mathrm{H}]^{2+} 1412.11$ found 1413.0, HPLC purity: $86 \%$. 


\subsection{Preparation of LCR Fragment.}

To study this region of the HPV 16 genome (Accession \# AF125673) quantitatively via CE, two fragments were generated. To generate the 7348-7798 bp fragment, two primer oligomers were used: (top strand) 5'- FAM-ATT GTG TTG TGG TTA TTC AT-3' and (bottom strand) 5'-HEX- CAT GTA TGA ACT AGG GTG AC-3', where FAM indicates the fluorescein dye and HEX indicates the hexachlorofluorescein dye. To generate the 7662-122 bp fragment by PCR, two primers were used: (top strand) 5'-FAM-TAA ATC ACT ATG CGC CAA CGC-3' and (bottom strand) 5'-HEXCCT GTG GGT CCT GAA ACA TTG-3'. All oligonucleotides were obtained from IDT (Coralville, lowa).

\subsection{Analysis of DNA-PA Interactions.}

\subsubsection{DNase I Footprinting.}

DNase I footprinting experiments were performed in TKMC buffer (10 mM Tris, $10 \mathrm{mM} \mathrm{KCl}, 5 \mathrm{mM} \mathrm{MgCl}_{2}$ and $5 \mathrm{mM} \mathrm{CaCl}_{2}$ ) with $10 \mathrm{mM} \mathrm{CHAPS}$ as previously described [26]. DNA concentrations were adjusted between $200 \mathrm{pM}$ and $1 \mathrm{nM}$ as needed. The reaction was initiated with 0.01-0.1 U DNase I; the amount of DNase I was dependent on the age of the enzyme, the DNA fragment, and DNA concentration. Reaction products were purified using the Qiagen MiniElute purification kit. Capillary electrophoresis (CE) analyses of samples were conducted at the DNA Core Facility at University of Missouri. Data were processed using Genemarker V1.97 software (Softgenetics LLC, State College, PA). DNase I cleavage products were mapped using 
Sanger sequencing (USB, Affymetrix, Santa Clara, CA). Peaks in the footprint were normalized to a peak not sensitive to PA concentration and plotted as fraction bound vs. PA concentration; the data were fit to a binding isotherm as previously described [26].

\subsubsection{Affinity Cleavage.}

0.8 eq of $\mathrm{Fe}\left(\mathrm{NH}_{4}\right)_{2}\left(\mathrm{SO}_{4}\right)_{2}$ was added to the polyamide-EDTA-Fe conjugate and incubated for $5 \mathrm{~min}$. The DNA fragment was then added to $1 \mathrm{nM}$ and the resulting mixture incubate 4-6 hours at room temperature in $10 \mathrm{mM}$ Tris, $10 \mathrm{mM}$ CHAPS, $\mathrm{pH}$ 7.5. The PA-EDTA conjugate concentration was varied from $5 \mathrm{nM}$ to $250 \mathrm{nM}$ and reported at $50 \mathrm{nM}$. To initiate the cleavage reaction, $5 \mu \mathrm{L}$ of fresh $100 \mathrm{mM}$ DTT was added to a 100 $\mu \mathrm{L}$ reaction and incubated $30 \mathrm{~min}$ to $4 \mathrm{hr}$. The reaction was quenched and products purified using a Qiagen PCR purification kit. Fragments were analyzed by capillary electrophoresis. Affinity cleavage results were mapped using Maxam-Gilbert reactions on 5' FAM endlabeled DNA [27].

\section{RESULTS}

\subsection{Contexts for PA Site Studies.}

The first reported study of anti-HPV PAs involved tandem (covalently linked) hairpin PAs that targeted a 12 bp recognition sequence for the HPV transcription and replication factor E2 [28]. The binding of the tandem PA to the minor groove of the E2 recognition sequence $\left(\mathrm{ACCN}_{6} \mathrm{GGT}\right)$ prevented this protein from binding the major groove [28]. 
PA1 and PA25 (Fig. 1) both represent evolution from the above design. They are both single hairpins with a ten bp recognition sequence of 5' $-\mathrm{W}_{2} \mathrm{GW}_{7}-3^{\prime}$ for PA1 (where $\mathrm{W}=\mathrm{A}$ or $\mathrm{T}$ ) and a $13 \mathrm{bp}$ recognition sequence and 5' $-\mathrm{W}_{2} \mathrm{GW}_{5} \mathrm{G} \mathrm{W}_{4}-3^{\prime}$ for PA25. As mentioned above, they have both been shown to nearly eliminate the HPV16 virus in vivo [13].

The LCR of HPV 16 starts at bp 7158 and ends at bp 83 of the circular genome. It features a number of binding sites for the $\mathrm{E} 2$ proteins and the $\mathrm{E} 1$ hexamer helicase assembly site [29] that are typically involved in initiating replication of the viral genome [13]. In this study, we examine PA1, PA2 and PA25 binding behaviors toward the sequence comprising 7348-122 bp of the HPV 16 genome. In this region, there are nine predicted PA1 recognition sites; five of these are concentrated in the region where E1 and E2 bind (positions commencing at nt 7903, 14, 15, 26, and 62 and indicated with bolded arrows in Fig. 2). There are no predicted perfect PA25 sites in this region, but it does feature 2 predicted single mismatch and almost 30 predicted double mismatch sites. Here "mismatch" refers to an alignment between PA residue and nt that does not conform to the reported PA-DNA recognition rules [30-36]. Typically this means a G or C appears where the PA residue targets $\mathrm{W}$ or $\mathrm{W}$ aligns with an $\mathrm{Im}$ residue.

Since this fragment of the genome is too large for accurate studies with capillary electrophoresis (CE) [21, 37-39], this sequence was divided into two overlapping fragments, 7348-7798 bp (451 bp) and 7662-122 bp (365 bp). 


\subsection{Studies of PA1-HPV16 LCR Interactions.}

\subsubsection{Affinity Cleavage with PA1-EDTA.}

In the affinity cleavage (AC) technique, hydroxyl radical cleavage of DNA at the binding site is achieved using FeEDTA [40-42]. Since the EDTA is located on the tail of the PA (open end of the hairpin; Fig. 1), the location of the tail on the DNA sequence is indicated with the cleavage patterns. Information about PA binding orientation is also provided by AC data (vide infra).

Figure 2 shows the affinity cleavage of PA1-EDTA with the 7348-122 bp DNA fragment of HPV16. As noted previously, 40-50 bp on the ends of the duplex are not accessible via CE [21]. 38 AC patterns were observed, and all AC sites have 3' shifts consistent with minor groove binders [43]. Some AC patterns are extended, suggestive of overlapping binding events (AC 5, 14, 22, and 24). Prediction of the PA1 binding sites according to the rules developed by the Dervan lab showed that one AC pattern can be rationalized by various possible predicted PA1 binding sites. Binding site assignments assume that forward sites are preferred over reverse ones (see below), and sites with fewer mismatches were preferred over those with a higher number of mismatches.

Relative to the HPV16 fragment studied previously (2150-2622), the 7348-122 region is slightly more GC rich ( $36.4 \%$ vs. $33.2 \%)$ and $40 \%$ longer but harbors about twice the number of $A C$ sites. This would suggest that either there are runs of more suitable PA1 sites or that there is a greater number of sites with multiple binding orientations. While there is a greater number of perfect sites in this region ( 7 vs. 3 ), they 
account for only a small fraction of the observed AC sites. As described below, the larger number of $\mathrm{AC}$ patterns result from sites with greater numbers of mismatches, and as a consequence of this, PA1 binding the same sequence in more than one orientation.

AC sites 1, 13, 30-32, and 34 can be rationalized by forward orientation perfect match binding sites only. Since single and double mismatch sites have already been shown to be abundant and generally of affinity similar to those observed for perfect mismatches [21], these sites will be tabulated but not discussed. Discussion is restricted to binding behaviors that are distinct from those observed earlier in the $2150-2672$ fragment [21].

AC sites 11, 19, 20, and the 5' part of AC 25 can be rationalized by forward triple mismatch sites only. In AC sites $\mathbf{9}$ and 10, there are two peaks on the top strand; on the bottom strand, there is only one AC peak. This could be explained by differences in resolution (bottom strand vs. top strand). AC sites $\mathbf{9}$ and $\mathbf{1 0}$ are unusual cases because AC 9 can be explained by PA1 bound to a forward triple mismatch site while AC 10 can only be rationalized by a quadruple mismatch or by PA1 binding to the DNA in some other conformation (half hairpin or linear).

AC sites 18 and $\mathbf{3 3}$ can be rationalized by PA1 bound to a forward quadruple mismatch site or to a reverse triple mismatch site; these cannot be distinguished.

For AC 12, the top strand $A C$ pattern is missing even though the $A C$ pattern further down the sequence was present (AC 13) and the bottom strand pattern was present for this same site. We suspect resolution issues associated with CE analysis. This AC pattern could be rationalized only by a forward quadruple mismatch site. 
In summary, for the 7348-122 bp region of the circular HPV16 genome, eight perfect match forward and four perfect match reverse PA1 binding sites were observed by AC. A large number of single, double, triple, and, more rarely, quadruple mismatch sites that bound in both forward and reverse fashion was also observed in this sequence.

\subsubsection{Quantitative Footprinting Studies of PA1.}

DNase I footprinting was used to evaluate all PA binding sites on this portion of the HPV16 genome. Integration positions were chosen based on location with respect to the footprint and for optimum signal-to-noise ratios [21]. In addition to the footprint itself, signal-to-noise ratios are influenced by the distance of the position from the dye and the slight sequence preference of DNase I [44, 45]. HPV16 sequences that are not amenable to cleavage by the enzyme have been reported [21] and are present in this region as well (7831-7840 and 7857-7866). It is also important to note that since DNase I is larger than PA1, steric encumbrance occurs and the footprint is always larger than that covered by the PA, so integration sites can lie outside the PA1 binding site.

The integration sites for DNase I footprinting are indicated with solid boxes in Fig. 2. Twenty-nine nucleotide positions were integrated to obtain $K_{d}$ 's (Table 1). In most cases, a single $\mathrm{K}_{d}$ corresponds to each identified AC site, even if there are multiple possible sequence possibilities for an AC pattern. Note that the $K_{d}$ for the PA1-EDTA conjugate as measured by footprinting is indistinguishable to that obtained for unmodified polyamide PA1 [21]. 
Table 1 summarizes the $K_{d}$ values obtained by DNase I. All of the $K_{d} s$ for perfect match sites range from $0.7 \mathrm{nM}$ to $1.9 \mathrm{nM}$, similar to those obtained previously for such sites on a different part of the HPV16 genome [21]. Most $\mathrm{K}_{d} \mathrm{~S}$ for single mismatch sites fall between 0.8 and $2.6 \mathrm{nM}$, demonstrating good tolerance for such sites (see below). There are three higher $\mathrm{K}_{d} \mathrm{~S}: 8.1 \mathrm{nM}$ at $7878,10.8 \mathrm{nM} \mathrm{K}_{d}$ quantitated at 7774 , and 13.1 $\mathrm{nM}$ at 7827 . The $7770-7779$ site is either a reverse single mismatch or a forward double mismatch site. The $K_{d}$ quantitated at 7827 could be the result of the binding affinity being determined at the mismatch nucleotide, where local binding may not be as avid. In this case, this was the location of the most favorable signal-to-noise ratio in the footprint.

$\mathrm{K}_{d} \mathrm{~S}$ for the double mismatch sites range from those typical of perfect and single mismatch sites ( $1.5 \mathrm{nM}$ to $3.4 \mathrm{nM}$ ) to those for three mismatches, with $\mathrm{K}_{d} \mathrm{~s}$ between 7 and $20 \mathrm{nM}$, the latter with a high relative error. Triple mismatch sites displayed slightly higher $\mathrm{K}_{d} \mathrm{~S}$ than typical of most with fewer mismatches (3.1-6.8 $\left.\mathrm{nM}\right)$. The same pattern holds for the quadruple mismatch binding sites (1.9 nM to $5.9 \mathrm{nM})$. Given the emphasis on perfect matches and the general intolerance of mismatches in the smaller, 6-8-ring hairpin polyamides [18, 46-51], we were somewhat surprised to observe such high affinities at sites with a large number of mismatches. However, we note that Sugiyama reports 18 bp specificity with a tandem hairpin in which three hairpins are linked together to form one large PA, though it is for a human telomeric repeat sequence and the actual measured specificity is low $\left(\mathrm{K}_{d}(\right.$ mismatch $) / K_{d}($ match $)$ is 2.6) [52]. 


\subsubsection{Effect of a Chiral $\gamma$ Turn on PA Binding Orientation.}

Previous reports indicated that for some shorter hairpin PAs (i.e. 6-ring) and longer PAs recognizing $10 \mathrm{bp}$, the introduction of a chiral center in the gamma turn of the hairpin PA resulted in a strong preference for the forward binding orientation [35, 53, 54]. Sugiyama found discrimination between $A / T$ and T/A base pairs with chiral $\beta$ hydroxy- $\gamma$-aminobutyric acid/ $\beta$-alanine pairs [55]. To examine how the introduction of a chiral group in the gamma turn of PA1, a chiral version of PA1 was prepared with chiral $\gamma$-turn (R)-2,4-diaminobutyric acid, giving PA2; the EDTA conjugate of PA2 was also prepared: PA2-EDTA (or amino-PA1). Binding sites on the 450 bp fragment (73487798) were evaluated using affinity cleavage at $50 \mu \mathrm{M}$ conjugate. As shown in Fig. 3, there is no appreciable difference between the binding sites for PA1-EDTA and aminoPA1-EDTA, or PA2-EDTA. Thus in the context of this larger PA, the introduction of an (R)-amino-gamma turn does not influence binding orientation of the PA family.

\subsection{Studies of PA25-HPV16 LCR Interactions.}

\subsubsection{Analysis of PA25 Affinity Cleavage Patterns.}

In spite of the fact that there are no perfect match sites for PA25 in this 678 region, 31 distinct AC patterns were observed for PA25 and are numbered in Fig. 4. Extended AC patterns 1, 2, 4, 6, 8, 17, 18, 22, 25, 28 have multiple peaks (high intensity surrounded by those with lower intensity) in their patterns for a total of 43 discernable PA25 binding sites. 
PA25 was initially designed to recognize the sequence $5^{\prime}-W_{2} G W_{5} G W_{4}-3$ ', the longest PA studied in this fashion to date. In attempting to reconcile AC patterns with probable binding sites, the first question is: How is the PA25 site anchored? Unlike mono-imidazole derivative PA1, PA25 has two Im residues and therefore the theoretical ability to recognize two G's on either side of a 5 residue/nt spacer (5'-GW $\left.{ }_{5} G^{\prime}-3^{\prime}\right)$. Is the $\mathrm{GW}_{5} \mathrm{G}$ site, or at least a $\mathrm{GN}_{5} \mathrm{G}$ site, required for PA25 binding? To address this, all 5'$\mathrm{GN}_{5} \mathrm{G}-3$ ' patterns were mapped on the fragment (Fig. S1). There are 14 on the top strand and 27 on the bottom, with a number on the latter overlapping.

What is more striking is that $16 \mathrm{AC}$ patterns, roughly half of the total number of AC patterns for PA25 (1, 5, 7,12, 13, 16, 17abc, 18a, 20, 25ab, 26, 27,31) exist in locations that are not near a 5'- $\mathrm{GN}_{5} \mathrm{G}-3$ ' sequence at all. Conversely, there are two 5'$\mathrm{GN}_{5} \mathrm{G}-3$ ' at $7620-7640$ that could be rationalized as multiple mismatch sites (triple at 7638 and quadruple at 7632) but for which no AC patterns are observed. It is possible that low signal-to-noise ratios common for positions over $200 \mathrm{bp}$ from the dye prevent us from detecting these sites. Regardless of this possibility, it is clear that the 5'-GN ${ }_{5} \mathrm{G}-3^{\prime}$ motif is not required for PA25 binding.

This begs the question of which, if either, $\mathrm{G}$ (the first (N-terminal) or second (internal) is more important in anchoring a site/rationalizing an AC pattern. To address this, the sequences at the observed AC patterns were analyzed (Tables S2-S4). The goal was to identify a binding site with the smallest number of mismatches, forward preferred if the number of mismatches is minimized, and then catalog whether the sequence has a first G, second G, both or neither. Two thirds of these sequences are either triple, quadruple, or quintuple mismatches. Over $80 \%$ of these sequences were 
anchored with one G or the other with no preference for one over the other with no obvious correlation with the number of mismatches. Only 6 sites had either zero or both G's. The A/T rich character of the genome is reflected in this observation.

Thus it appears that neither $\mathrm{G}$ is critical to the PA25 recognition sequence, and if the fragment were even more $A / T$ rich, we predict that both PAs would populate those sites as much as any other part of the sequence.

\subsubsection{Quantitative Footprinting Studies with PA25.}

Unlike for PA1 where the binding sequences were far more straightforward, the data do not permit us to establish exact sequences for PA25 binding. For this reason, regions supported by DNase I footprints are presented in lieu of specific sequences (Fig. 4.). Almost all of the sequence accessible via CE exhibits PA25 footprinting behavior at $10 \mathrm{nM}$ PA (DNA is $1 \mathrm{nM}$ ). These results are consistent with the size of DNase I, the relatively large size of PA25, and the high tolerance for mismatches. Discrepancies between footprinting and $\mathrm{AC}$ patterns cannot be interpreted to due to signal-to-noise issues in those regions.

The $27 \mathrm{~K}_{d} \mathrm{~S}$ obtained from the sites of integration appear in Table $\mathbf{S} 1$ and are summarized in Fig. 5. 18 of the $\mathrm{K}_{d} \mathrm{~s}$ are between 0.7 and $1.9 \mathrm{nM}$. There are a few slightly weaker $\mathrm{K}_{\mathrm{d}} \mathrm{s}$ but all are less than 3-fold above this range and thus not significantly different. All of these values compare well to the $K_{d}$ of $1.2 \pm 0.5 \mathrm{nM}$ obtained for two overlapping perfect match sites integrated at position 3662 (outside the LCR; Gaofei He, unpublished results). Given that a large majority of sites are likely to 
feature triple or quadruple mismatch sequences, this indicates a high tolerance for mismatches. This is discussed in comparison to PA1 below (Section 4.2).

\section{DISCUSSION}

\subsection{Hairpin Polyamide Orientation of DNA Binding.}

There are numerous examples of modifications to smaller hairpin PAs (6-10 rings) that influence binding orientation. For example, the 8-ring ImPyPy- $\gamma-P y P y P y \beta D p$ binds in the forward direction with a $\mathrm{K}_{\mathrm{d}} 16$-fold stronger than a reverse sequence. Neutralizing the $C$ terminal charge via acetylation decreases this preference 4-fold (Table 2, Entry 1; [56]). More dramatic are chiral modifications to the turn of the hairpin. When a chiral $\alpha-$ amino substitution is introduced into the $\gamma$-aminobutyric acid ( $\gamma$-turn) in the $R$ configuration of a 6-ring and an 8-ring hairpin PA, preferences for the forward orientation over the reverse are over 1000-fold (Table 2, Entries 2,3; [35, 57].

The study of Rucker et al. [53] with 10-ring PAs and $\beta$ alanine substitution illustrates the complexity that can emerge. ImImPyPyIm- $\gamma-P y P y P y P y P y-\beta-D p$ binds in a decidedly forward orientation to the extent that it binds a predicted reverse site in a forward fashion, which corresponds to a double mismatch (Table 2, Entry 4). Reverse binding is too weak to quantitate but represents a forward preference of at least 500 -fold. Substituting $\beta$ adjacent to the $N$-terminal imidazoles (Imlm- $\beta$-Pylm- $\gamma$-PyPy- $\beta-P y P y-\beta-D p$ ) results in a PA that prefers to bind what is a predicted reverse site in the forward fashion, with a double mismatch but with a $\mathrm{K}_{\mathrm{d}}$ similar to that predicted for the reverse orientation (i.e., no thermodynamic discrimination between forward and reverse orientations). 
In another case, the substitution of one pyrrole for $\beta$-Ala in the polyamide with a $\beta$-substituted $\gamma$-turn results in a preference for the reverse orientation of binding. This was based on thermal melting data (Table 2, Entry 5) [58]. $\alpha$-substitution (R) at the $\gamma$ turn resulted in a forward binding orientation preference.

Engineering sequences to test forward and reverse binding is much more difficult for a large PA with a demonstrated tolerance for mismatches [21] than for the PAs just discussed. Here we rely on the affinity cleavage technique and a PA2-EDTA, a version of PA1 that is modified with an amine in a chiral $(\mathrm{R})-\gamma$-turn, $(\mathrm{R})_{-\gamma(\mathrm{NH} 2)}$. While such modifications have been shown to influence binding orientation in smaller PAs, $(\mathrm{R})_{-\gamma(\mathrm{NH} 2)}$ has no appreciable effect on AC patterns as exhibited by PA2-EDTA (vs. PA1-EDTA as shown in Fig. 3). This result is entirely consistent with the high tolerance of large PAs for mismatches.

\subsection{Comparison of PA1 and PA25 Binding in the LCR.}

\subsubsection{Affinity Cleavage.}

Given that both PA1 and PA25 are active against HPV16 and were originally designed to bind at or near the E1/E2 protein-DNA binding sites for an HPV sequence, a comparison of binding behaviors is instructive. Since the size difference between these PAs results in footprints that also differ in size, AC patterns are more readily compared than footprints themselves (Fig. 6). In making comparisons, we note that signal-to-noise ratios were generally better for PA1 than PA25; this had an impact on interpreting data far from the dye (the 5 ' end of the DNA fragment). Due in part to this fact, we were better able to obtain PA1 data further out from the dye (longer fragments) 
than for PA25. This resulted in some locations where data for one strand (top or bottom, depending on the label) was more accessible for PA1 than PA25.

With that in mind, some observations emerge: First, the number of $A C$ patterns (i.e., binding events) is similar for PA1 and PA25: 34 for the former (5 compounded, that is, having more than one maxima) and 31 for the latter (10 compounded). This means that the general specificity is not dramatically different, even though PA25 is $40 \%$ longer than PA1 (see below). Second, while the footprints are extensive, the fact that there are numerous but distinct $A C$ patterns for both indicate there are discrete binding sites/orientations in both cases. In other words, while the high tolerance for mismatches means that exact sequence binding rules do not exist, neither PA binds indiscriminately. Third, while there is some overlap of AC intensities (black, Fig. 6), there are many places where the AC patterns are distinct from one another (red for PA25 and blue for PA1, Fig. 6). This indicates that the PAs are not targeting the same local regions (e.g. 10-30 bps) and therefore are not similarly targeting any DNA structure driven by local sequence-dependent structures (e.g., minor groove width, roll, propeller twist, and helical twist; [59]). Finally, while more-active PA25 may target approximately the same number of sites in the LCR as PA1, the greater length of PA25 means that it more completely blankets or enshrouds the viral DNA in a way that PA1 cannot. This correlates with activity and may provide important insights into antiviral behavior.

\subsubsection{Binding Constants.}

A comparison of the distribution of $K_{d} s$ for the two PAs appears in Fig. 5. While most $\mathrm{K}_{\mathrm{d}} \mathrm{S}$ for both PAs are between $0.7-4 \mathrm{nM}$, there is clearly a greater proportion of 
tighter $\mathrm{K}_{d} \mathrm{~S}$ measured for PA25 than for PA1. This means that taken as aggregate data in this region of the HPV16 genome, PA25 tolerates a greater number of mismatches than PA1. That is, the average $K_{d}$ is lower (1.7 nM for PA25; $4.5 \mathrm{nM}$ for PA1). This is reasonable given that the number of potential hydrogen bonds with bases is also greater (24 vs. 17) for PA25 than PA1. Thus it appears that when it comes to hairpin PA length and sequence specificity, PA1 length is probably at or possibly past the maximum in terms of benefit to specificity. Longer PA25 tolerates mismatches better than PA1 and is therefore less specific. These properties are at least partly correlated with antiviral behavior, in that PA25 is a better, broad-spectrum antiviral compound, with superior anti-HPV18 activity than PA1 [13].

\subsection{Mechanistic Implications.}

The above discussion leads to the question of whether or not it matters where either PA binds or if there is some larger effect that is responsible for the antiviral behavior. Both compounds have low $\mathrm{IC}_{50}$ 's toward HPV16 [13] and both have high binding-site density in the LCR region. It is expected that this pattern would extend to other parts of the genome. Recently we reported that PA25 induces the DNA damage response (DDR) in HPV-infected cells bearing the unintegrated viral genome (episome) [14], presumably triggered by a change the shape of the episome brought on by PA binding. The high number of binding sites for both PA1 and PA25 is consistent with this suggestion, as is the relatively rigid nature of the PA molecules, which would strain a supercoiled structure. It is less clear is if there are specific binding events, rather than a global effect, that are responsible for inducing the DDR. Extending from that is whether 
or not PA1 and PA25 share a common antiviral mechanism at the molecular level; more specifically, if precisely the same binding events are responsible for exactly the same elements of the DDR being induced by each compound, or if there is a combination of binding events that can induce viral DNA degradation. This question continues to drive our efforts to elucidate the details of the interactions of antiviral PAs with their DNA targets.

\section{ACKNOWLEDGMENTS}

We thank NIH for AI083803 awarded to JKB and NanoVir, LLC for financial support. JKB is part owner of NanoVir, LLC. We thank NanoVir, LLC for the loan of equipment and the use of active antiviral compounds. We thank the DNA Core at the University of Missouri for DNA fragment analysis. We thank the Danforth Plant Science Center for HRMS [National Science Foundation (NSF) Grant DBI 0922879]. We thank Prof. Ben Bythell for mass spectrometry data. The Agilent $600 \mathrm{MHz}$ NMR spectrometer was obtained using funds from the NSF (\#0959360). 


\section{REFERENCES}

[1] M.E. Parks, E.E. Baird, P.B. Dervan, Recognition of 5'-(A,T)GG(A,T)2-3' Sequences in the Minor Groove of DNA by Hairpin Polyamides., J. Amer. Chem. Soc. 118 (1996) 6153-6159.

[2] J.M. Turner, E.E. Baird, P.B. Dervan, Recognition of Seven Base Pair Sequences in the Minor Groove of DNA by Ten-Ring Pyrrole-Imidazole Polyamide Hairpins, J. Amer. Chem. Soc. 119 (1997) 7636-7644.

[3] S. White, E.E. Baird, P.B. Dervan, On the pairing rules for recognition in the minor groove of DNA by pyrrole-imidazole polyamides, Chem. Biol. 4 (1997) 569-578.

[4] Z.-F. Tao, T. Fujiwara, I. Saito, H. Sugiyama, Rational Design of SequenceSpecific DNA Alkylating Agents Based on Duocarmycin A and Pyrrole-Imidazole Hairpin Polyamides, J. Am. Chem. Soc. 121 (1999) 4961-4967.

[5] T. Vaijayanthi, T. Bando, K. Hashiya, G.N. Pandian, H. Sugiyama, Design of a new fluorescent probe: Pyrrole/imidazole hairpin polyamides with pyrene conjugation at their $\mathrm{Y}$-turn, Bioorg. Med. Chem. 21 (2013) 852-855.

[6] D. Harris, M. Stewart, A. Sielaff, K. Mulder, T. Brown, H. Mackay, M. Lee, Solution phase synthesis of imidazole- and pyrrole-containing hairpin polyamides, Heterocyclic Communications 13 (2007) 17-24.

[7] J.A. Henry, N.M. Le, B. Nguyen, C.M. Howard, S.L. Bailey, S.M. Horick, K.L. Buchmueller, M. Kotecha, D. Hochhauser, J.A. Hartley, W.D. Wilson, M. Lee, Targeting the Inverted CCAAT Box 2 in the Topoisomerase lla Promoter by JH-37, an Imidazole-Pyrrole Polyamide Hairpin: Design, Synthesis, Molecular Biology, and Biophysical Studies, Biochemistry 43 (2004) 12249-12257.

[8] A. Sielaff, A. Cooper, H. Mackay, T. Brown, C. O'Hare, J. Kluza, M. Kotecha, M. Le, D. Hochhauser, J.A. Hartley, M. Lee, Binding of f-PIP and JH-37 to the inverted CCAAT box-2 of the topoisomerase lla promoter, Abstracts of Papers, 233rd ACS National Meeting, Chicago, IL, United States, March 25-29, 2007 (2007) MEDI-134.

[9] X. Xiao, P. Yu, H.-S. Lim, D. Sikder, T. Kodadek, A cell-permeable synthetic transcription factor mimics, Angewandte Chemie, International Edition Eng. 46 (2007) 2865-2868, S2865/2861-S2865/2810.

[10] X. Xiao, P. Yu, H.-S. Lim, D. Sikder, T. Kodadek, Design and synthesis of a cellpermeable synthetic transcription factor mimic, J. Combinatorial Chem. 9 (2007) $592-600$.

[11] N.G. Nickols, J.O. Szablowski, A.E. Hargrove, B.C. Li, J.A. Raskatov, P.B. Dervan, Activity of a Py-Im Polyamide Targeted to the Estrogen Response Element, Molecular Cancer Therapeutics (2013).

[12] J.M. Gottesfeld, C. Melander, R.K. Suto, H. Raviol, K. Luger, P.B. Dervan, Sequence-specific recognition of DNA in the nucleosome by pyrrole-imidazole polyamides, J. Mol. Biol. 309 (2001) 615-629. 
[13] T.G. Edwards, K.J. Koeller, U. Slomczynska, K. Fok, M. Helmus, J.K. Bashkin, C. Fisher, HPV episome levels are potently decreased by pyrrole-imidazole polyamides, Antiviral Res. 91 (2011) 177-186.

[14] T.G. Edwards, T.J. Vidmar, K. Koeller, J.K. Bashkin, C. Fisher, DNA Damage Repair Genes Controlling Human Papillomavirus (HPV) Episome Levels under Conditions of Stability and Extreme Instability, PLoS ONE 8 (2013) e75406.

[15] T.G. Edwards, M.J. Helmus, K. Koeller, J.K. Bashkin, C. Fisher, Human papillomavirus episome stability is reduced by aphidicolin and controlled by DNA damage response pathways, J. Virology 87 (2013) 3979-3989.

[16] C. Fisher, Recent Insights into the Control of Human Papillomavirus (HPV) Genome Stability, Loss, and Degradation, J Clin Med 4 (2015) 204-230.

[17] T.F. Martínez, J.W. Phillips, K.K. Karanja, P. Polaczek, C.-M. Wang, B.C. Li, J.L. Campbell, P.B. Dervan, Replication stress by Py-Im polyamides induces a noncanonical ATR-dependent checkpoint response Nucleic Acids Res. 421 (2014) $1546-11559$.

[18] J.M. Turner, S.E. Swalley, E.E. Baird, P.B. Dervan, Aliphatic/Aromatic Amino Acid Pairings for Polyamide Recognition in the Minor Groove of DNA, J. Amer. Chem. Soc. 120 (1998) 6219-6226.

[19] C.A. Hawkins, E.E. Baird, P.B. Dervan, D.E. Wemmer, Analysis of hairpin polyamide complexes having DNA binding sites in close proximity, J. Amer. Chem. Soc. 124 (2002) 12689-12696.

[20] K.J. Koeller, G.D. Harris, K. Aston, G. He, C.H. Castaneda, M.A. Thornton, T.G. Edwards, S. Wang, R. Nanjunda, W.D. Wilson, C. Fisher, J.K. Bashkin, DNA Binding Polyamides and the Importance of DNA Recognition in Their Use as Gene-Specific and Antiviral Agents, Med. Chem. 4 (2014) 338-344.

[21] G. He, E. Vasilieva, J. Harris, G. D. , K.J. Koeller, J.K. Bashkin, C.M. Dupureur, Binding Studies of a Large Antiviral Polyamide to a Natural HPV Sequence, Biochimie 102 (2014) 83-91.

[22] E.E. Baird, P.B. Dervan, Solid phase synthesis of polyamides containing imidazole and pyrrole amino acids, J. Amer. Chem. Soc. 118 (1996) 6141-6146.

[23] C.M. Dupureur, J.K. Bashkin, K. Aston, K.J. Koeller, K.R. Gaston, G. He, Fluorescence assay of polyamide-DNA interactions, Anal. Biochem. 423 (2012) 178-183.

[24] J. Bashkin, C. Fisher, K.J. Koeller, inventors, NanoVir LLC., Polyamides for treating human papilloma virus, US Patent 2007-US6133 (2007).

[25] D.M. Chenoweth, D.A. Harki, J.W. Phillips, C. Dose, P.B. Dervan, Cyclic PyrroleImidazole Polyamides Targeted to the Androgen Response Element, J. Amer. Chem. Soc. 131 (2009) 7182-7188.

[26] J.K. Bashkin, K. Aston, J.P. Ramos, K.J. Koeller, R. Nanjunda, G. He, C.M. Dupureur, W. David Wilson, Promoter scanning of the human COX-2 gene with 8ring polyamides: Unexpected weakening of polyamide-DNA binding and selectivity by replacing an internal N-Me-pyrrole with beta-alanine, Biochimie 95 (2013) 271-279.

[27] A.M. Maxam, W. Gilbert, Sequencing end-labeled DNA with base-specific chemical cleavages, Methods Enzymol. 65 (1980) 499-560. 
[28] T.D. Schaal, W.G. Mallet, D.L. McMinn, N.V. Nguyen, M.M. Sopko, S. John, B.S. Parekh, Inhibition of human papilloma virus E2 DNA binding protein by covalently linked polyamides, Nucleic Acids Res. 31 (2003) 1282-1291.

[29] H. Romanczuk, F. Thierry, P.M. Howley, Mutational analysis of cis elements involved in E2 modulation of human papillomavirus type 16 P97 and type 18 P105 promoters, J. Virology 64 (1990) 2849-2859.

[30] K. Muzikar, J. Meier, D. Gubler, J. Raskatov, P. Dervan, Expanding the Repertoire of Natural Product-Inspired Ring Pairs for Molecular Recognition of DNA. doi: 10.1021/ol202285y, Org. Lett. 13 (2011) 5612-5615.

[31] P.B. Dervan, B.S. Edelson, Recognition of the DNA minor groove by pyrroleimidazole polyamides, Curr Opin Struct Biol 13 (2003) 284-299.

[32] C.C. Wang, U. Ellervik, P.B. Dervan, Expanding the recognition of the minor groove of DNA by incorporation of beta-alanine in hairpin polyamides, Bioorg. Med. Chem. 9 (2001) 653-657.

[33] A.R. Urbach, P.B. Dervan, Toward rules for 1:1 polyamide:DNA recognition, Proc Natl Acad Sci USA 98 (2001) 4343-4348.

[34] P.B. Dervan, Molecular recognition of DNA by small molecules, Bioorg. Med. Chem. 9 (2001) 2215-2235.

[35] D.M. Herman, E.E. Baird, P.B. Dervan, Stereochemical Control of the DNA Binding Affinity, Sequence Specificity, and Orientation Preference of Chiral Hairpin Polyamides, J. Amer. Chem. Soc. 120 (1998) 1382-1391.

[36] M.E. Parks, E.E. Baird, P.B. Dervan, Optimization of the Hairpin Polyamide Design for Recognition of the Minor Groove of DNA, J. Amer. Chem. Soc. 118 (1996) 6147-6152.

[37] D.O. Wilson, P. Johnson, B.R. McCord, Nonradiochemical DNase I footprinting by capillary electrophoresis, Electrophoresis 22 (2001) 1979-1986.

[38] M. Zianni, K. Tessanne, M. Merighi, R. Laguna, F. Tabita, Identification of the DNA Bases of a DNase I Footprint by the Use of Dye Primer Sequencing on an Automated Capillary DNA Analysis Instrument, J. Biomol. Tech. 17 (2006 ) 103113.

[39] P.A. Sivapragasam S, Grove A. , A recommended workflow for DNase I footprinting using a capillary electrophoresis genetic analyzer, Anal. Biochem. 481 (2015) 1-3.

[40] S. White, E.E. Baird, P.B. Dervan, Effects of the A.T/T.A degeneracy of pyrrole-imidazole polyamide recognition in the minor groove of DNA, Biochemistry 35 (1996) 12532-12537.

[41] J.S. Taylor, P.G. Schultz, P.B. Dervan, DNA affinity cleaving : Sequence specific cleavage of DNA by Distamycin-EDTA - Fe(II) and EDTA-distamycin Fe(II), Tetrahedron 40 (1984) 457-465.

[42] T.D. Tullius, J.A. Greenbaum, Mapping nucleic acid structure by hydroxyl radical cleavage, Current opinion in chemical biology 9 (2005) 127-134.

[43] P. Schultz, J. Taylor, P. Dervan, Design and Synthesis of a Sequence-Specific DNA Cleaving Molecule. (Distamycin-EDTA)iron(II), J. Amer. Chem. Soc. 104 (1982) 6861-6863.

[44] H. Koohy, T.A. Down, T.J. Hubbard, Chromatin Accessibility Data Sets Show Bias Due to Sequence Specificity of the DNase I Enzyme, PLoS One 8 (2013) e69853. 
[45] B. Heddi, J. Abi-Ghanem, M. Lavigne, B. Hartmann, Sequence-Dependent DNA Flexibility Mediates DNase I Cleavage, J. Mol. Biol. 395 (2010) 123-133.

[46] Y.W. Han, G. Kashiwazaki, H. Morinaga, T. Matsumoto, K. Hashiya, T. Bando, Y. Harada, $\mathrm{H}$. Sugiyama, Effect of single pyrrole replacement with beta-alanine on DNA binding affinity and sequence specificity of hairpin pyrrole/imidazole polyamides targeting 5'-GCGC-3', Bioorg Med Chem 21 (2013) 5436-5441.

[47] Y.N.V. Gopal, M.W. Van Dyke, Combinatorial Determination of Sequence Specificity for Nanomolar DNA-Binding Hairpin Polyamides, Biochemistry 42 (2003) 6891-6903.

[48] C.C. O'Hare, D. Mack, M. Tandon, S.K. Sharma, J.W. Lown, M.L. Kopka, R.E. Dickerson, J.A. Hartley, DNA sequence recognition in the minor groove by crosslinked polyamides: The effect of $\mathrm{N}$-terminal head group and linker length on binding affinity and specificity, Proc. Natl. Acad. Sci. USA 99 (2002) 72-77.

[49] D.S. Pilch, N. Poklar, E.E. Baird, P.B. Dervan, K.J. Breslauer, The thermodynamics of polyamide-DNA recognition: hairpin polyamide binding in the minor groove of duplex DNA, Biochemistry 38 (1999) 2143-2151.

[50] S. Swalley, E.E. Baird, P.B. Dervan, Discrimination of 5'-GGGG-3', 5'-GCGC-3', and 5'-GGCC-3' sequences in the minor groove of DNA by eight-ring hairpin polyamides, J. Amer. Chem. Soc. 119 (1997) 6953-6961.

[51] S.E. Swalley, E.E. Baird, P.B. Dervan, Effects of $\gamma$-Turn and $\beta$-Tail Amino Acids on Sequence-Specific Recognition of DNA by Hairpin Polyamides, J. Amer. Chem. Soc., 121 (1999) 1113-1120.

[52] Y. Kawamoto, A. Sasaki, K. Hashiya, S. Ide, T. Bando, K. Maeshima, H. Sugiyama, Tandem Trimer Pyrrole-Imidazole Polyamide Probes Targeting 18 Base Pairs in Human Telomere Sequences, Chem. Sci. 6 (2015 ) 2307-2312.

[53] V.C. Rucker, C. Melander, P.B. Dervan, Influence of b-alanine on hairpin polyamide orientation in the DNA minor groove, Helvetica Chimica Acta 86 (2003) 1839-1851.

[54] P.M. Reddy, J.W. Toporowski, A.L. Kahane, T.C. Bruice, Recognition of a 10 base pair sequence of DNA and stereochemical control of the binding affinity of chiral hairpin polyamide-Hoechst 33258 conjugates, Bioorg. Med. Chem. Lett. 15 (2005) 5531-5536.

[55] W. Zhang, S.K. Jiang, Y.L. Wu, C.X. Guo, H.F. Zhang, H. Sugiyama, X.L. Chen, Discrimination between $T / A$ and $A / T$ base pairs of pyrrole-imidazole polyamides substituted with chiral beta-hydroxy-gamma-aminobutyric acid/beta-alanine pairs, ChemBioChem 13 (2012) 47-50.

[56] S. White, E.E. Baird, P.B. Dervan, Orientation Preferences of Pyrrole-Imidazole Polyamides in the Minor Groove of DNA, J Am Chem Soc 119 (1997) 8756-8765.

[57] S.M. Tsai, M.E. Farkas, C.J. Chou, J.M. Gottesfeld, P.B. Dervan, Unanticipated differences between alpha- and gamma-diaminobutyric acid-linked hairpin polyamide-alkylator conjugates, Nucleic Acids Res 35 (2007) 307-316.

[58] J.L. Meier, A.S. Yu, I. Korf, D.J. Segal, P.B. Dervan, Guiding the design of synthetic DNA-binding molecules with massively parallel sequencing, J. Amer. Chem. Soc. 134 (2012) 17814-17822. 
[59] T. Zhou, L. Yang, Y. Lu, I. Dror, A.C. Dantas Machado, T. Ghane, R. Di Felice, R. Rohs, DNAshape: a method for the high-throughput prediction of DNA structural features on a genomic scale, Nucleic Acids Res. 41 (2013) W56-62. 
Table 1. PA1 Sites on 7348-122 Fragment of HPV16. ${ }^{a}$

\begin{tabular}{|c|c|c|c|c|c|c|c|}
\hline$A C$ & & Sequence & & Position & Site type & Integration nt & $\mathrm{K}_{\mathrm{d}}, \mathrm{nM}$ \\
\hline 1 & GTTTT & TTGTTTTATA & TATAC & 7399-7408 & Perfect & & \\
\hline 2 & AAATT & TAGTATATAT & AAAAC & $7415-7406$ & Perfect & 7424 & $1.8 \pm 0.3$ \\
\hline 2 & CCGCG & ATGTTTTAAA & TCATA & $7424-7415$ & Perfect $^{\mathrm{b}}$ & & \\
\hline 3 & GGTTG & AAGCTACAAA & ATGGC & $7448-7439$ & Double & 7443 & $3.4 \pm 0.7$ \\
\hline 4 & GTTGC & ATGCTTTTTG & GCACA & $7466-7475$ & Double & 7469 & $2.3 \pm 1.0$ \\
\hline $5 a, b$ & AAAAT & GTGTTTTTTT & AAATA & $7485-7494$ & Single & 7489 & $1.0 \pm 0.3$ \\
\hline $5 b$ & ACAAA & ATGTGTTTTT & TTAAA & 7483-7492 & Single & & \\
\hline $5 b$ & TGTGT & TTTTTTAAAT & AGTTC & 7489-7498 & Single & & \\
\hline 6 & TGACA & TAGAACTATT & TAAAA & $7505-7496$ & Single & & \\
\hline 7 & AACTA & TAGTTTAAAC & TTGTA & $7518-7527$ & Single & 7519 & $2.6 \pm 1.4$ \\
\hline 8 & CGTAC & AAGTTTAAAC & TATAG & $7529-7520$ & Single & 7528 & $1.5 \pm 0.5$ \\
\hline 9 & ATGGC & AAGCAGGAAA & CGTAC & $7544-7535$ & Triple & 7542 & $6.8 \pm 0.7$ \\
\hline 10 & CATGC & GTGCCAAATC & ССTGT & $7552-7561$ & Quadruple & 7556 & $1.9 \pm 0.5$ \\
\hline 11 & AATCC & СTGTTTTССТ & GACCT & $7563-7572$ & Triple & 7572 & $3.1 \pm 2.7$ \\
\hline 12 & ACTGC & TTGCCAACCA & TTCCA & $7585-7594$ & Quadruple & 7592 & $5.9 \pm 1.6$ \\
\hline 13 & TTCCA & TTGTTTTTTA & CACTG & $7600-7609$ & Perfect & 7608 & $1.9 \pm 0.7$ \\
\hline $14 a$ & GTGCA & GTGTAAAAAA & CAATG & $7612-7603$ & Single & & \\
\hline $14 b$ & GCACT & ATGTGCAACT & ACTGA & $7619-7628$ & Triple & & \\
\hline 15 & TCACT & ATGTACATTG & TGTCA & $7640-7649$ & Double & 7648 & $1.5 \pm 0.5$ \\
\hline 16 & ACATT & GTGTCATATA & AAATA & $7649-7658$ & Double & & \\
\hline 16 & ACACA & ATGTACATAG & TGATT & $7638-7647$ & Double & & \\
\hline 17 & GCATA & GTGATTTATT & TTATA & $7669-7660$ & Single & 7662 & $1.4 \pm 0.6$ \\
\hline 18 & CCAAC & GССТTACATA & CCGCT & 7681-7690 & Quadruple & 7685 & $4.4 \pm 2.1$ \\
\hline 18 & GGTTG & CGGAATGTAT & GGCGA & $7690-7681$ & Quadruple & & \\
\hline 19 & AACAG & CGGTATGTAA & GGCGT & 7693-7684 & Triple & & \\
\hline 20 & AATCC & GTGTATAAAA & ACCGA & $7702-7711$ & Single & 7704 & $1.9 \pm 0.0$ \\
\hline 20 & AGGCA & CATATTTTTG & GCTTG & 7704-7713 & Triple & & \\
\hline 20 & TAGGC & ACATATTTTT & GGCTT & 7703-7712 & Double & & \\
\hline 21 & TTGGC & TTGTTTTAAC & TAACC & $7716-7725$ & Single & 7722 & $1.5 \pm 0.5$ \\
\hline $22 a$ & TAGGT & TAGTTAAAAC & AAGCC & 7727-7718 & Single & & \\
\hline $22 b$ & ССТАA & TTGCATATTT & GGCCA & $7734-7743$ & Single & 7739 & $2.6 \pm 1.2$ \\
\hline 23 & GGCAT & AAGGTTTAAA & СТTСТ & 7749-7758 & Single & 7754 & $1.6 \pm 0.2$ \\
\hline $24 a$ & CTTAG & AAGTTTAAAC & СТTAT & $7761-7752$ & Single & & \\
\hline $24 b$ & GGCCT & TAGAAGTTTA & АACCT & 7764-7755 & Single & & \\
\hline $24 b$ & TCCGG & TTGATTTACT & GTGGG & 7770-7779 & Single & 7774 & $10.8 \pm 0.2$ \\
\hline 25 & CTAGG & GTGTCATTTA & GTTGG & $7782-7773$ & Double & & \\
\hline 25 & CACCC & TAGTTCATAC & ATGAA & 7785-7794 & Double & 7792 & $7.3 \pm 2.0$ \\
\hline 26 & AGTTC & ATGTATGAAC & TAGGG & $7796-7787$ & Double & & \\
\hline 27 & AAGGT & TAGTCATACA & TTGTT & $7812-7821$ & Double & 7817 & $19.8 \pm 8.0$ \\
\hline $28 a$ & ATACA & TTGTTCATTT & GTAAA & $7822-7831$ & Single & 7827 & $13.1 \pm 1.1$ \\
\hline $28 b$ & TTCAT & TTGTAAAACT & GCACA & 7830-7839 & Single & & \\
\hline 29 & GTTGC & TTGTAAATGT & GTAAC & $7882-7873$ & Single & 7878 & $8.1 \pm 1.4$ \\
\hline 29 & CAAGC & AАCTTATATA & ATAAT & 7885-7894 & Single & 7890 & $0.8 \pm 0.2$ \\
\hline 30 & TAGTT & TAGTATTATT & ATATA & 7903-7894 & Perfect & 7899 & $0.7 \pm 0.3$ \\
\hline 31 & TATAC & ATGAATTATT & GTAGT & $15-6$ & Perfect & 11 & $1.4 \pm 0.8$ \\
\hline 31 & AATTC & ATGTATAAAA & CTAAG & $14-23$ & Perfect & 18 & $1.1 \pm 0.1$ \\
\hline 32 & GCCCT & TAGTTTTATA & CATGA & $26-17$ & Perfect & & \\
\hline 33 & GGCGT & AACCGAAATC & GGTTG & $35-44$ & Quadruple & 35 & $3.5 \pm 0.8$ \\
\hline 34 & CCGGT & TAGTATAAAA & GCAGA & $62-71$ & Perfect & 64 & $1.2 \pm 0.5$ \\
\hline
\end{tabular}

${ }^{a}$ Position corresponds to the PA arrowhead/where the sequence begins. $4 \mathrm{nt}$ flanking sequences are included.

${ }^{\mathrm{b}}$ Reverse orientation. 
Table 2. Influence of Substitutions in Hairpin PA on Orientation of Binding ${ }^{a}$

\begin{tabular}{|c|c|c|c|c|c|}
\hline $\begin{array}{c}\text { Case } \\
\#\end{array}$ & Polyamide & $\begin{array}{c}\text { \# } \\
\text { Rings }\end{array}$ & $\begin{array}{c}R \\
\text { VS. } \\
\text { S }\end{array}$ & $\begin{array}{c}\text { Target } \\
\text { Sequence }\end{array}$ & $\mathrm{Fwd} / \mathrm{Rev}^{\mathrm{b}}$ \\
\hline \multirow{2}{*}{$1^{c}$} & & \multirow{2}{*}{6} & & \multirow{2}{*}{ WWWCW } & 16 \\
\hline & & & & & 4 \\
\hline \multirow{2}{*}{$2^{d}$} & $\overline{\beta D p}$ & \multirow{2}{*}{6} & $\mathrm{R}$ & \multirow{2}{*}{ WWWCW } & $>1000$ \\
\hline & & & $S$ & & 5 \\
\hline \multirow{2}{*}{$3^{e}$} & & \multirow{2}{*}{8} & $\mathrm{R}$ & \multirow{2}{*}{$\begin{array}{c}\text { WCWCCW } \\
\text { W }\end{array}$} & $>1000$ \\
\hline & & & $S$ & & 0.05 \\
\hline \multirow[b]{2}{*}{$4^{f}$} & & \multirow[b]{2}{*}{10} & & \multirow{2}{*}{$\begin{array}{c}\text { WCCWWC } \\
\text { W }\end{array}$} & $\geq 500$ \\
\hline & & & & & 2 \\
\hline \multirow{3}{*}{$5^{g h}$} & & \multirow{3}{*}{8} & & \multirow{3}{*}{ WCGWC } & Fwd \\
\hline & & & & & Rev \\
\hline & $\mathrm{H}_{3} \mathrm{~N}$ & & $\mathrm{R}$ & & Fwd \\
\hline
\end{tabular}

${ }^{a}$ Open circles represent pyrrole, closed circles represent imidazole, $\beta$ represents $\beta$-Ala, half circle is $\mathrm{\gamma}$-turn. $\mathrm{Dp}=\mathrm{N}, \mathrm{N}$-dimethylaminopropylamine. ${ }^{\mathrm{b}}$ Refers to ratio of $\mathrm{K}_{\mathrm{a}}$ 's for binding in the forward orientation to $\mathrm{K}_{\mathrm{a}}$ for binding in the reverse orientation. ${ }^{\mathrm{C}}[56]$; ${ }^{\mathrm{d}}[35]$; [57]; [53]; ${ }^{9}[58]$. ${ }^{\text {}}$ Preference determined by melting temperature experiments. 


\section{FIGURE LEGENDS}

Fig. 1. Structures, Predicted Recognition Sequences, and Sample Binding Orientations for PA1 and PA25. Top: Structures of PA1, PA25, amino-PA1 and relevant EDTA conjugates. Bottom: Target sequences for PA1 and PA25 and

alternative binding orientations. Open circles = pyrrole; closed circles = imidazole; open diamond $=\beta$ alanine; $\mathrm{W}=\mathrm{A} / \mathrm{T}$. The arrowhead indicates the location of the polyamide tail and EDTA group. $f$ refers to the forward binding orientation (amino terminus aligns with 5 ' end of target sequence); $r$ refers to the reverse binding orientation (amino terminus aligns with the 3 ' end of the target sequence.

Fig. 2. Sequence Map of PA1 Affinity Cleavage (AC) and Footprinting in the 7348122 LCR Region of HPV16. Affinity cleavage was observed at $50 \mathrm{nM}$ PA1-FeEDTA conjugate. Since signal-to-noise ratios vary with fragment length, red vertical arrows indicate intensities relative to other arrows in a site, not to other sites. Small arrow heads reflect particularly weak affinity cleavage. Solid horizontal arrows indicate PA1 sites consistent with AC data. Bolded horizontal arrows indicate perfect-match (canonical) sequences. Boxed nt indicates a site of integration. E protein binding sites are indicated in green. Brackets indicate where the various overlapping duplexes begin and end. See text for details. Possible reverse binding sites are omitted for clarity, as are forward double mismatches in regions where they overlap significantly with perfect or single mismatch sites.

Fig. 3. Effect of Chiral Turn on Affinity Cleavage Patterns. Partial electropherograms of the 7348-7798 portion of HPV16 when treated with A PA1-EDTA; B amino-PA1EDTA. $1 \mathrm{nM}$ DNA duplex, $50 \mathrm{nM}$ PA. See experimental for additional details.

Fig. 4. Sequence Map of PA25 Affinity Cleavage (AC) and Footprinting in the 7348122 LCR Region of HPV16.

Fig. 5. Distribution of Kds obtained from the 7348-122 portion of the LCR of HPV16 for PA1 and PA25. Table S1 summarizes the integration positions and $K_{d} s$ with errors for PA25.

Fig. 6. Overlay of PA1 (blue) and PA25 (red) AC patterns in the 7348-122 LCR Region of HPV16. Black arrows indicate overlap. 


\section{Figure 1}

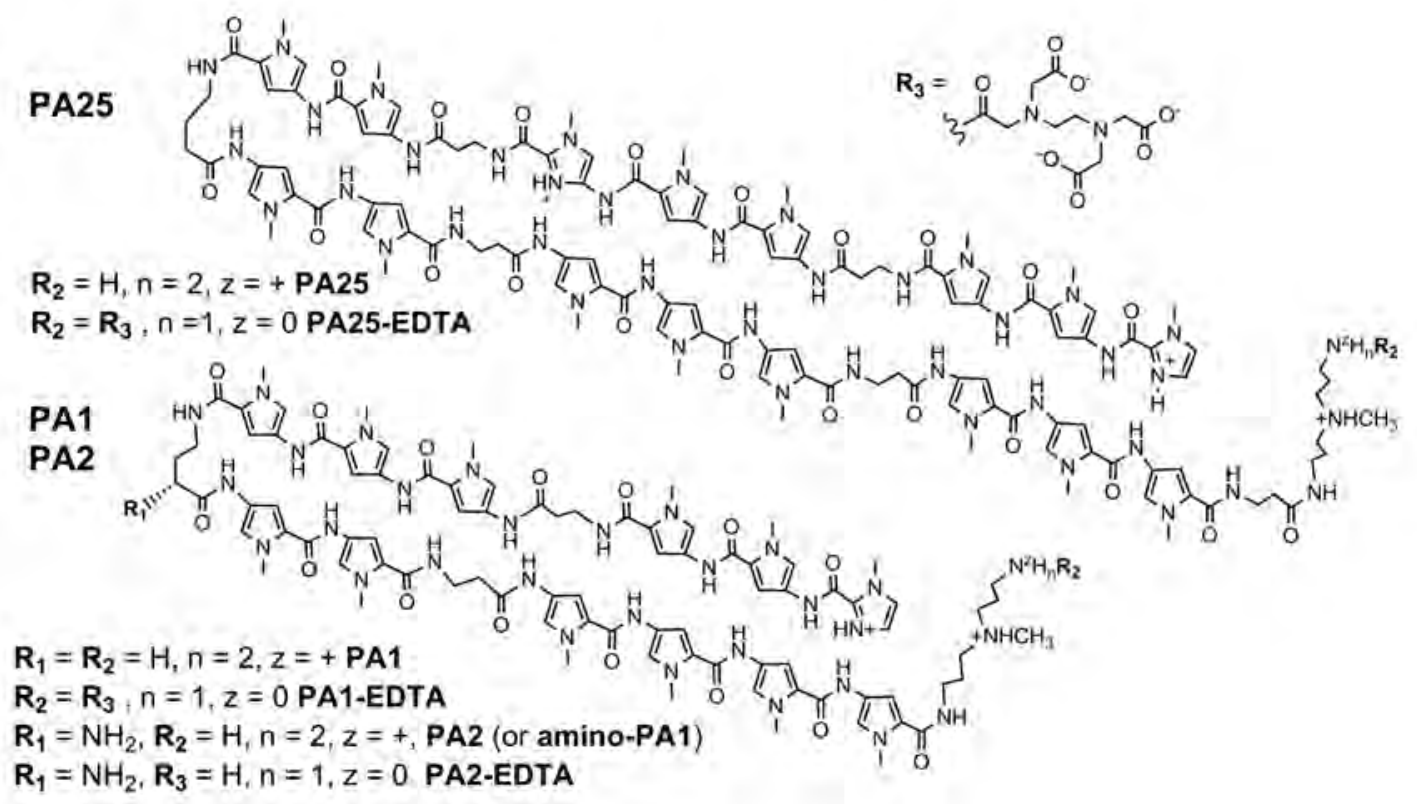

\section{PA1}

$5^{\prime}-$ W W G W W W W W W W-3'

f
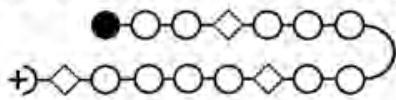

$3^{\prime}-\mathrm{W}$ W C W W W W W W W-5,

3'-W W W W W W W G W W-5' Cororore

r

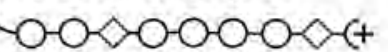

$5^{\prime}-\mathrm{W}$ W W W W W W C W W-3'
PA25

$5^{\prime}-$ W W G W W W W W G W W W W-3'

- $-0-00-00$ $+0-000000000$

$3^{\prime}-\mathrm{W}$ W C W W W W W C W W W-5'

$5^{\prime}-$ W W W W G W W W W W G W W-3'

Co- $00-000-000$

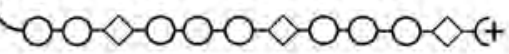

$3^{\prime}-\mathrm{W} W \mathrm{~W}$ W C W W W W W C W W-5' 


\section{Figure 2}

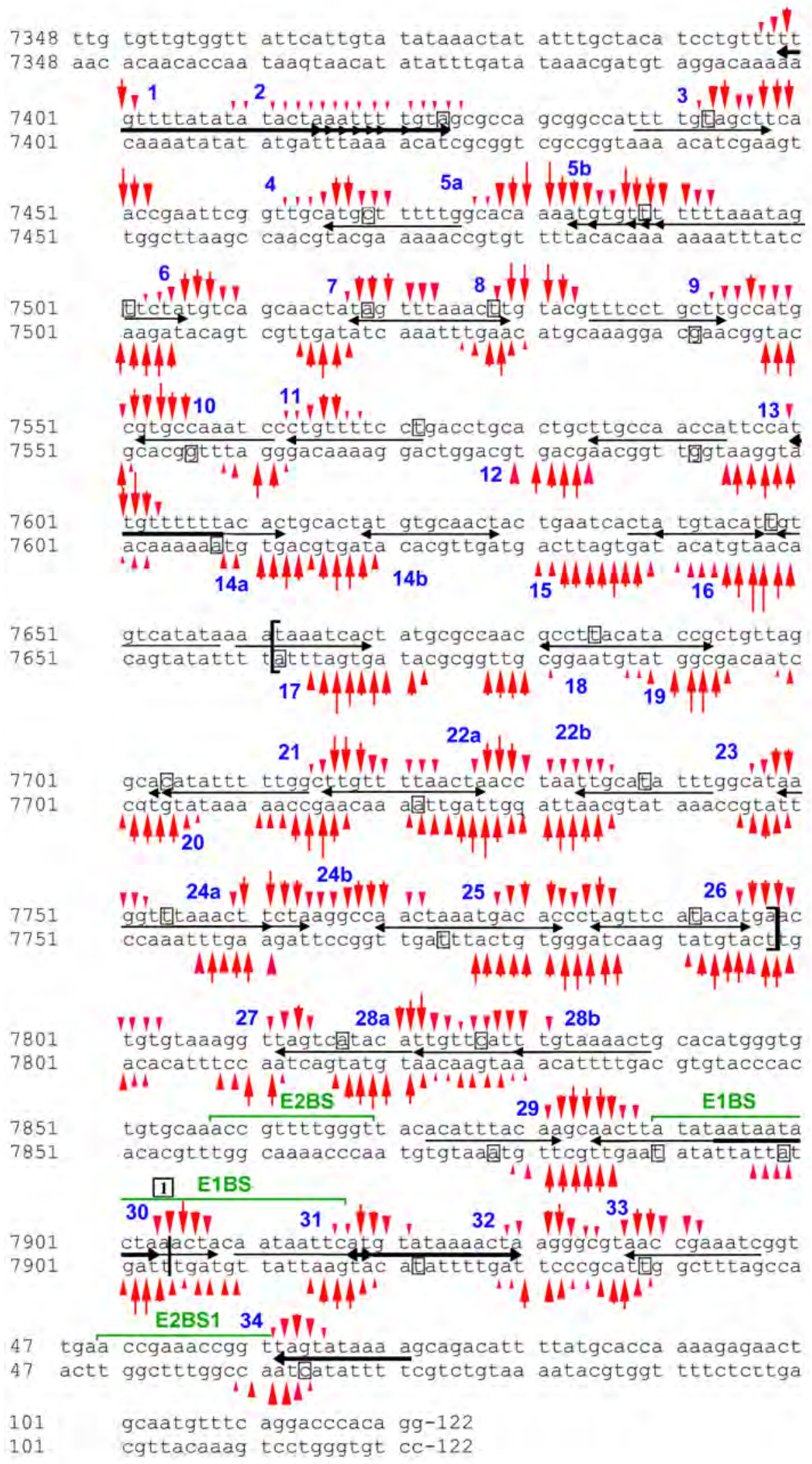


Figure 3
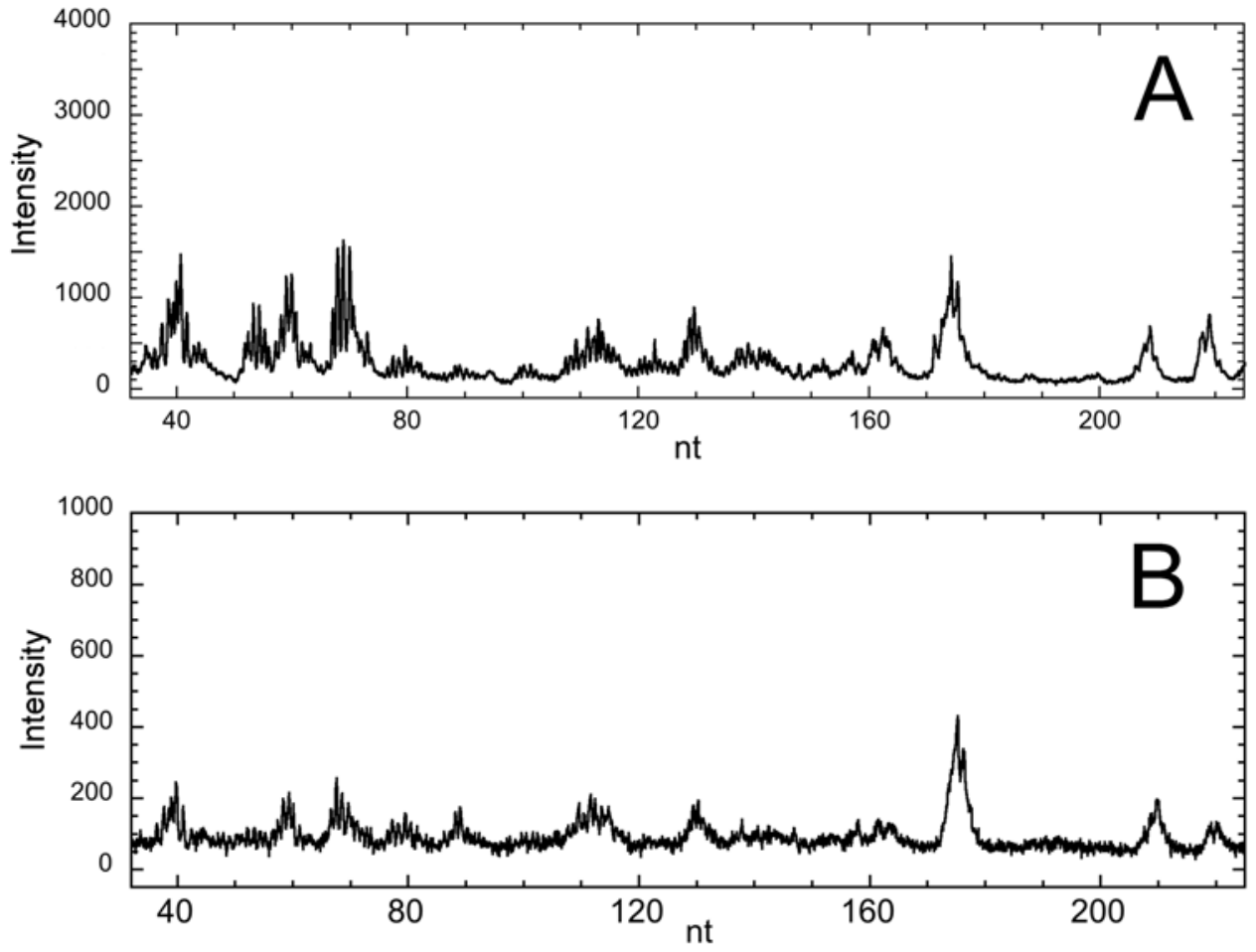


\section{Figure 4}

7348 ttg tgttgtggtt attcattgta tataaactat atttgctaca tcctgtttt

7348 aac acaacaccaa taagtaacat atatttgata taaacgatgt aggacaaaaa

Ia

gtttatata tactaaattt tgtagcgcca gcggccattt tgtagctta

7401 caaatatat atgatttaaa acatcgcggt cgccggtaaa acatcgaagt

accgaattcg gtetgcatgct ttttggcaca aaatgtgttt ttttaaatag tggcttaagc caacgtacga aaaccgtgt tttacacaaa aaalttatc

aagatacagt cgttgatatc aatttgaa atgcaaagga cgaacggtac

7551

7551

7601

7601

7651

7651

7701

7701

7751

7751

7801

7801

7851

7851

7901

7901

47

47

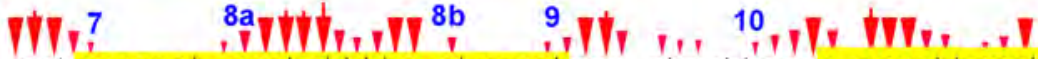 cgtgccaaat ccctgttttc ctgacctgca ctgcttgcca accattccat gcacggttta gggacaaadg gactggacgt gacgaacggt tggtaaggta}

\section{W11 $12, \boldsymbol{W}$}

tgtttttac actgcactat gtgcaactac tgaatcacta tgtacattgt acaaaa@tg tgacgtgata cacgttgatg acttagtgat acatgtaact

41

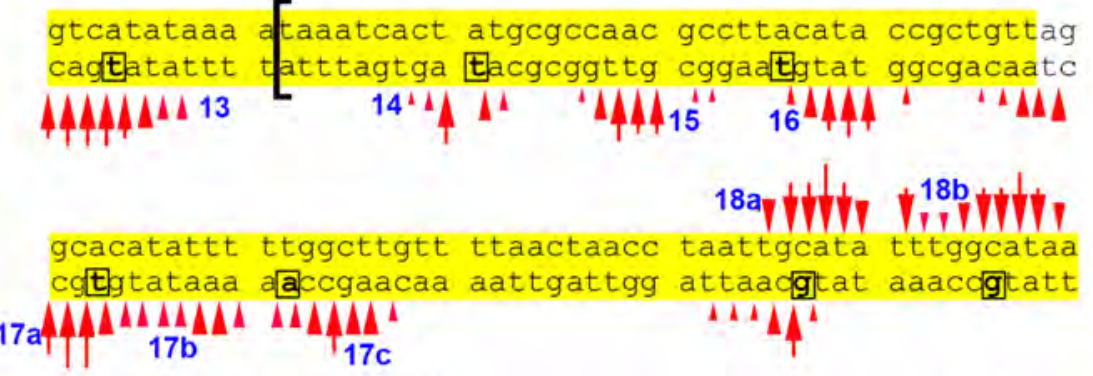

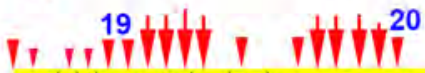

21 ggtttaaact tctaaggcca actaaatgtc accctagttc atacatga po

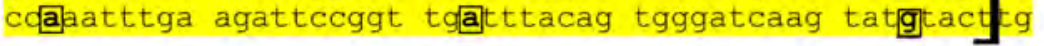

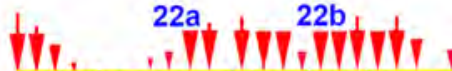

tgtgtaaagg ttagtcatac attgttcatt tgtaaaactg cacatgggtg acacatttcc 国atcagtatg taacaagtaa acattttgac gtgtacccac

$$
23 \text { E2BS } 24 / 7 \text { E1BS }
$$

tgtgcaaacc gttttgggtt acacatttac aagcaactta tataataata acacgtttgg caaaadccaa tgtgtaaatg ttcgttga at atattattat
$\Delta M \Lambda^{4}$
${ }^{1} M 4 \Lambda^{4}$
25a MNMA $\Lambda_{25 \mathrm{~b}}^{\Delta M M A}$

\section{E1BS}

ctaalactaca ataattcatg tataaacta agggcgtaac cgaaatcggt gatttgatgt tattaagtala atattttga田 tcccgcattg gctttagcca
III TT E2BS
${ }_{26}^{14} \Lambda \Lambda^{4}$
$M \|$ MY $^{27}$
1)
IIIII

tgaa ccgaaaccgg ttagtataaa agcagacatt ttatgcacca aaagagaact actt ggctttggcc aatcatatt tcgtctgtaa atacgtggt tttctcttga

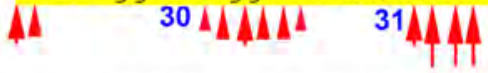

101 gcaatgtttc aggacccaca gg-122

Cgttacaaag tcctgggtgt cc-122 
Figure 5

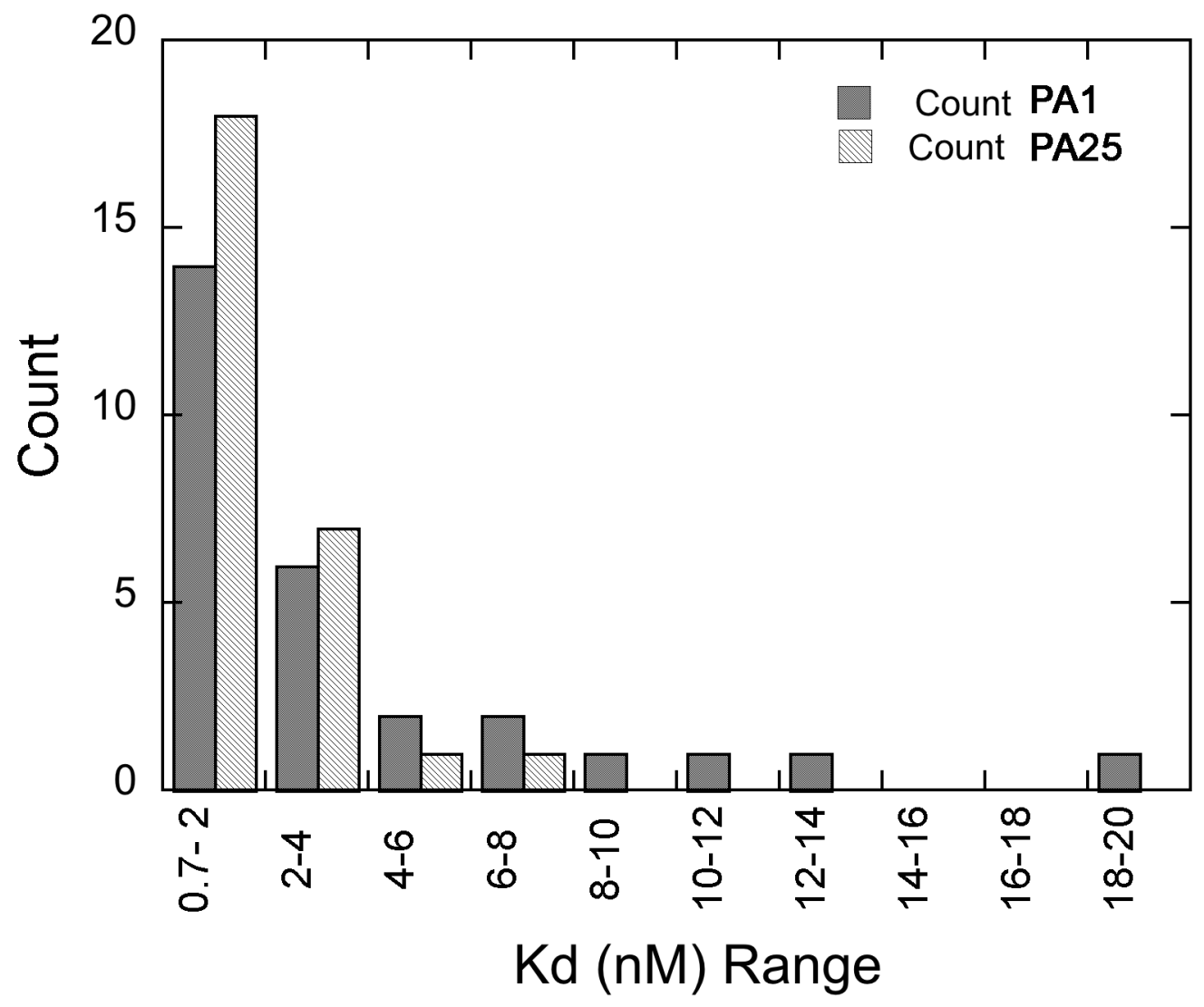




\section{Figure 6}

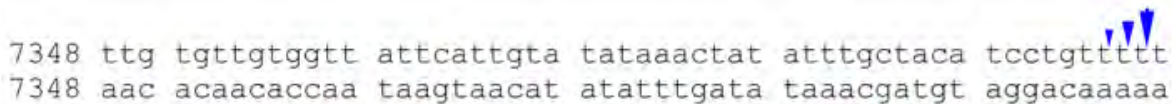

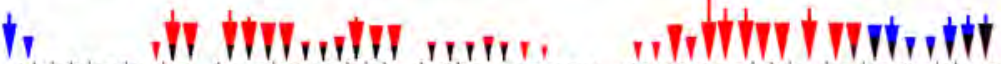

7401 gtttatata tactaaatt tgtagcgcca gcggccatt tgtagcttca

7401 caaatatat atgatttaaa acatcgcggt cgccggtaaa acatcgaagt

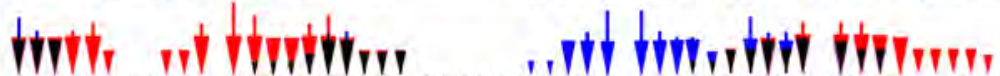

7451 accgaattcg gttgcatgct ttttggcaca aaatgtgttt tttaaatag

7451 tggcttaagc caacgtacga aaaccgtgt tttacacaaa aaattatc

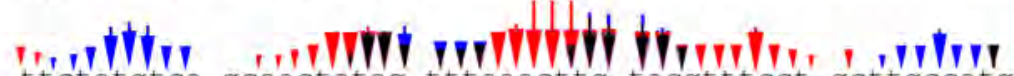

7501 ttctatgtca gcaactatag tttaaacttg tacgttcct gcttgccatg 7501 aagatacagt cgttgatatc aatttgaac atgcaaagga cgaacggtac

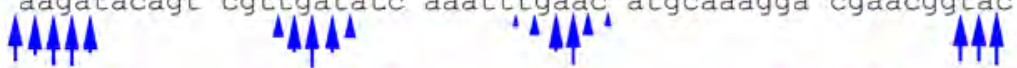

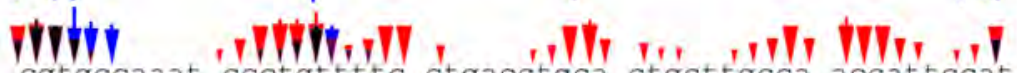

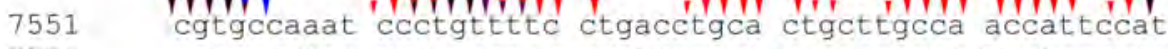
7551 gcacggttta gggacaaaag gactggacgt gacgaacggt tggtaaggta Hith A $W_{1}, W_{r}$

7601 tgtttttac actgcactat gtgcaactac tgaatcacta tgtacattgt 7601 acaaaaatg tgacgtgata cacgttgatg acttagtgat acatgtaaca 11\|\|\|\|\|\|$^{4}$

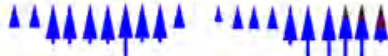

7651

7651

gtcatataa a Faatcact atgcgccaac gecttacata ccgctgttag cagtatattt thttagtga tacgcggttg cggatgtat ggcgacaatc

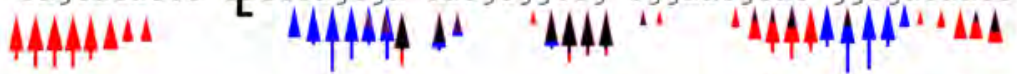

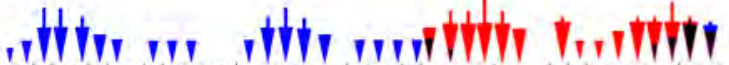
gcacatattt ttggcttgtt ttaactaacc taattgcata tttggcataa cgtgtataaa aaccgaacaa aattgattgg attaacgtat aaccgtatt

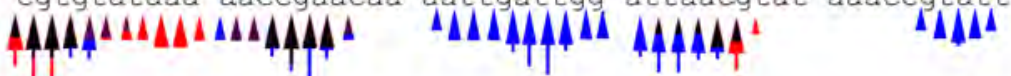

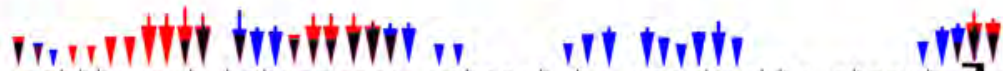

7751 ggtttaact tctaaggcca actaatgtc accctagttc atacatga 7751 ccaatttga agattccggt tgatttacag tgggatcaag tatgtact 9 Alili 1

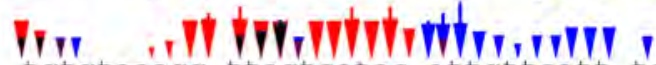

7801 tgtgtaaagg ttagtcatac attgttcatt tgtaaactg cacatgggtg

7801 acacatttcc aatcagtatg taacaagtaa acattttgac gtgtacccac

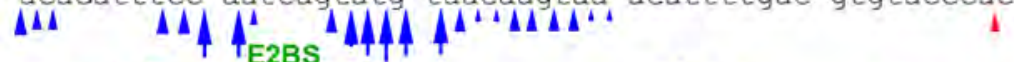

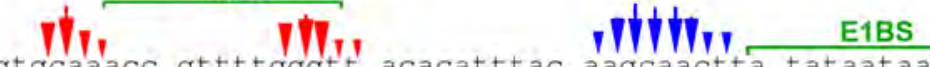

7851 tgtgcaáacc gttttgggtt acacatttac aagcaactta tataataata 7851 acacgtttgg caaacccaa tgtgtaaatg ttogttgaat atattattat

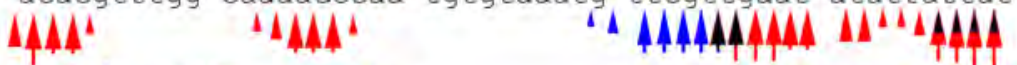

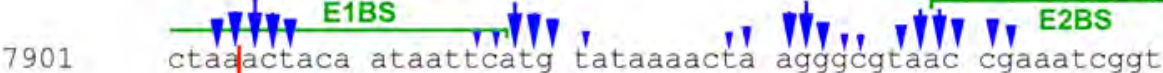
7901 gatttgatgt tattaagtac atatttgat tcccgcattg gctttagcca

ccgaaaccgg ttagtataaa agcagacatt ttatgcacca aaagagaact

47 actt ggctttggcc aatcatattt tegtctgtaa aatacgtggt tttctcttga $\mathbf{\Lambda}$

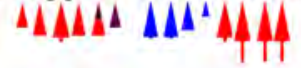

101 gcaatgtttc aggacccaca gg-122

Cgttacaaag tcctgggtgt cc-122 